\title{
Isfahan Mescid-i Şah'ta Hayvan Tasvirli Çini Pano - İslam Sanatı mı Hıristiyan Sanatı mı?
}

\author{
Belkıs Doğan*
}

\section{Öz}

İslam sanatı özgün bezeme motifleri bakımından oldukça zengin bir birikime sahiptir. Tabiattakini olduğu gibi resmetmeme ilkesi, tevhid ve sonsuzluk vurgusu İslam mimarîsi ve aynı zamanda süsleme sanatlarının temel çıkış noktası olmuştur. Bu gayeyle oluşturulan geometrik süslemelerin yanında rûmî ve hatâyî gibi ileri derecede üslûplaştırılmış kompozisyonlar, İslam sanatına mücerret bir boyut kazandırmıştır. Bununla birlikte figüratif bezemeler de İslam sanatında önemli bir yer teşkil etmektedir. Ancak figüratif unsurların dînî mimarîde bilhassa camilerde kullanımı oldukça nadirdir. Az sayıdaki bu örneklerde karşımıza çıkan insan veya hayvan tasvirlerinin büyük bir kısmı yine doğrudan ibadet mekânında yer almayıp taç kapı ve cephe duvarlarında görülmektedir. Çalışmamıza konu olan Isfahan Şah/İmam Camii ise yaban hayvanların tasvir edildiği çini pano ile diğer örneklerden ayrılmaktadır. Zira söz konusu yapıda hayvan tasvirli pano, şebistan adı verilen birimin kuzey cephesinde kıbleye dönük olarak yerleştirilmiş ve ileri derece üslûplaştırma uygulanmamıştır. Aynı zamanda bu kısım, cemaatin kalabalık olduğu durumlarda namaz kılınan bir bölümdür. Çalışmamızın temel sorusunu oluşturan husus ise bahsi geçen panonun teknik, üslûp ve içerik bakımından çok benzerlerinin Isfahan Yeni Culfa bölgesinde bulunan kiliselerin süsleme programında dikkate değer bir yer ediniyor olmasıdır. Bu makalede cami ve kilise mimarîsinde müşterek kullanılan hayvan tasvirli çini panolar, üslûbun özellikleri, ortaya çıkışı ve Hıristiyan-İslam sanatı etkileşimi bakımından ele alınacaktır.

Anahtar Kelimeler: İslam Sanatı, Hıristiyan Sanatı, Figür, Hayvan Tasviri, Çini

Araştırma Görevlisi, Marmara Üniversitesi, Sosyal Bilimler Enstitüsü-İslam Tarihi ve Sanatlar1 Bölümü, belkis.dogan@marmara.edu.tr, ORCID: 0000-0003-3343-0229. 


\title{
A Tile Panel with Animal Depiction in Isfahan Shah Mosque: Islamic Art or Christian Art?
}

\author{
Belkıs Doğan*
}

\begin{abstract}
Islamic art has a considerably rich history in regard to authentic decoration motifs. The principle of depicturing the nature different than reality and the emphasis of tawhid and eternity have been the fundamental starting points of both Islamic architecture and the decorative arts. In addition to the geometrical ornaments created for this purpose, the highly stylized compositions such as rumi (eslimi/ arabesque) and khatai have brought an abstract dimension to Islamic art. Besides, figurative decorations have an essential place in Islamic art. However, the use of figurative elements in religious architecture, especially in mosques, is highly exceptional. Yet, these rare examples of human and animal depictions that are observed in religious architectures are mainly encountered on the portal and facade walls rather than worship sections. The Isfahan Shah/Imam Mosque, which is the subject of this study, differs from other examples. Because, in this architecture, the tile panel that depicts wild animals has been placed on the north side of the Shebistan which faces the Qibla and additionally, advanced stylization which is usually observed in other examples has not been applied for this tile. At the same time, this part of the mosque is used for prayers when there is a high number of worshippers. The interesting point which formed the research question of this paper is that the tile mentioned above has remarkable similarities with the tiles used in the decorations of the churches located in Isfahan Julfa region in terms of technique, style and content. In this article, the tile panels that depict animal figures used in mosque and church architecture will be analyzed in terms of the emergence and characteristics of their style and Christian - Islamic art interaction.
\end{abstract}

Keywords: Islamic Art, Christian Art, Figure, Animal Depictions, Tile Work

Res. Asst., Marmara University, Institute of Social Sciences-Islamic History and Art Department, belkis.dogan@marmara.edu.tr, ORCID: 0000-0003-3343-0229. 


\section{Giriş}

İslam sanatının fikrî düzlemde ana prensiplerini oluşturan Kur'ân-1 Kerîm'de resim ve heykel dahil sanata muhalif herhangi bir ifade bulunmamakla birlikte çeşitli hadis rivayetlerinde şirke götürme endişesiyle canlı tasvire karşı takınılan olumsuz tutum, Müslüman sanatkârın sanatını dışavurumunda üslûplaştırma ve soyutlama yöntemlerini tercih etmesini kuvvetlendirmiştir. Buna mukabil İslam sanatlarında erken dönemlerden itibaren figüratif bezeme örnekleri görülmektedir. Hattâ mimarî, kitap sanatları, dokuma ve evanî gibi sanatın herhangi bir dalında hiçbir figüratif bezeme kullanmadığını öne sürebileceğimiz bir İslam devleti tarihte mevcut değildir. İslam sanatında, yazılı olmayan kurallarla sistemleşmiş bir şekilde, her bir motifin yahut bezeme unsurunun sıklıkla kullanıldığ yerler bulunmaktadır. Söz konusu figüratif bezemeler de dînî mimarîden büyük oranda uzak tutulmuştur. ${ }^{1}$ Ancak figüratif unsurların dînî mimarîde kullanıldığ 1 örnekler nadir de olsa mevcuttur. Isfahan Nakş-1 Cihan Meydanı'ndaki Mescid-i Şah da bu örneklerden biridir. Mimarî özellikleri ve süsleme programı açısından İran sanatının ve bilhassa Safevî döneminin şaheserleri arasında sayılan yapının taç kapısında, revaklarında ve şebistan adı verilen kışlık namaz bölmesinde figüratif unsurlar yer almaktadır. Çalışmamızda ele alacağımız yaban hayvanların tasvir edildiği çini pano, ileri derecede bir üslûplaştırma söz konusu olmadan caminin ibadet edilen birimine yerleştirilmesi ve Isfahan'daki Ermeni nüfusun yoğunlukta olduğu Yeni Culfa'daki kiliselerde yer alan çinilerle teknik, üslûp ve içerik bakımından çok benzeşmesiyle diğer figüratif bezeme örneklerinden farklil1k arz etmektedir.

Esasen İslam medeniyetinde mimarî ve sanat alanında diğer din ve medeniyetlerle etkileşimler İslam'ın ilk yıllarından itibaren âşinâ olunan bir durumdur. Erken Dönem İslam eserlerinde, inşa edildikleri bölgelerin mimarî özellikleri ve tezyînât malzemelerinin kullanımı oldukça yaygındır. Nitekim bu dönemin yapılarında Bizanslı ustaların çalıştırıldıkları bilinmektedir. ${ }^{2}$ Fakat konu tezyînâtta kullanılan motiflere geldiğinde, bilhassa İslam sanatının özgünlügünü kazandığı hicrî ikinci asırdan itibaren diğer kül-

Titus Burckhardt, İslam Sanatı: Dil ve Anlam, çev. Turan Koç (İstanbul: Klasik Yayınları, 2005), 34-35.; Selçuk Mülayim, İslam Sanatı (İstanbul: İSAM Yayınları, 2010), 156-157.

2 Burckhardt, İslam Sanatı, 30, 47.; Robert Hillenbrand, İslam Sanatı ve Mimarlığı, çev. Çiğdem Kafescioğlu (İstanbul: Homer Kitabevi, 2005), 14-15.; Oleg Grabar, İslam Sanatının Oluşumu, çev. Nuran Yavuz (İstanbul: Kanat Kitap, 2004), 177. 
türlerden farklı desen ve kompozisyonlar tercih edildiği fikri hakimdir. ${ }^{3}$ Ancak Isfahan Mescid-i Şah'taki örnek, istisna olmakla birlikte bu teoriyi sarsacak mahiyettedir. Zira burada Ermenilerin İslam'a özgü çini malzeme ve rûmî motiflerini kullanma hususunda imtina etmedikleri görüldüğü gibi Safevîlerin de Beytüllahim Kilisesi'nin duvarlarının neredeyse tamamını kaplayan ve üzerinde dînî mimarîye aykırı olduğu kabul edilen figüratif unsurların bulunduğu çini panoyu ibadet mekânına yerleştirme noktasında bir tereddüt yaşamadıkları anlaşılmaktadır.

İslam mimarîsinde istisna bir örneğin ele alınacağı bu çalışmada öncelikle Mescid-i Şah'in mimarî ve tezyînî özellikleri hakkında bilgi verilecektir. Daha sonra hayvan tasvirli çini pano, üslûbunun ortaya çıkışı ve özellikleri bakımından detaylandırılacak ve son olarak da cami ve kiliselerde kullanılan bu müşterek bezemenin İslam sanatı mı Hıristiyan sanatı mı olduğu konusu tartışlacaktır.

\section{Isfahan Mescid-i Şah}

\subsection{Mimarî Özellikleri}

Isfahan'da Nakş-1 Cihan Meydanı'nda bulunan Şah Camii, Safevî hanedanlığı dönemine ait bir eserdir. Yapının inşası Şah I. Abbas zamanında, M.1612 yılında başlamış olup Şah Safî̀ döneminde, M.1630-31 yıllarında tamamlanmıştır. ${ }^{4}$ Caminin güneydoğu ve güneybatıdan bitişik olan medreseleri ile tezyînî unsurlarının, zaman içerisinde tamamlandığı bilinmektedir. Yap1; Mescid-i Şah, Mescid-i Sultânî-i Cedîd, Câmi-i Abbâsî gibi isimlerle anılmaktadır. 1979 İran İslam Devrimi'nin ardından ise Mescid-i İmam ismi kullanılır hale gelmiştir. ${ }^{5}$

Şah I. Abbas, şehrin merkezini Selçuklular devrinde inşa edilen, şehrin sembolü ve en büyük camisi olan Isfahan Mescid-i Cuması'nın bulunduğu bölgeden yeni kurduğu Meydan-1 Şah'a taşıma gayesiyle bu bölgede

Burckhardt, İslam Sanatı, 13, 23, 35.; Grabar, Islam Sanatının Oluşumu, 78.; Hillenbrand, İslam Sanatı ve Mimarlığl, 62.; Mülayim, İslam Sanatı, 146.

4 Sheila Blair ve Johnathan Bloom, "Safevi Dönemi Mimarisi”, içinde İslam Sanatı ve Mimarisi, ed. Markus Hattstein ve Peter Delius (İstanbul: Literatür Yayınları, 2007), 512.

5 Engin Beksaç, "Mescid-i Şah", Türkiye Diyanet Vakfi İslam Ansiklopedisi (DİA), (Ankara: TDV Yayınları, 2004), XXIX: 291. 
birçok anıt eser inşa ettirmiştir (Foto.1-Plan 1). Bunların en önemlilerinden biri de şehrin yeni cuma camisi kabul edilen Mescid-i Şah olmuştur (Foto.2). ${ }^{6}$ Nakş-1 Cihan meydanı olarak da bilinen Meydan-1 Şah'ın güney kenarında yer alan yapı, Selçukludan intikal eden dört ayvanlı avlulu plan üzere inşa edilmiştir. Caminin taç kapısı meydanın güney revakının tam ortasında yer almakla birlikte cami, kıble istikametinde olması nedeniyle taç kapıya 45 derecelik açı oluşturmaktadır (Plan 2). ${ }^{7}$ Gerek meydana açılan taç kapı gerekse ana ayvan ve kubbeli mekânın girişi çifte minareli bir tasarıma sahiptir (Foto.2). Üç tarafi çift katlı revaklarla çevrili avlunun ortasında dikdörtgen bir havuz bulunmaktadır. Yapının kitabelerinde iki farklı mimarın ismi geçmektedir. Bunlardan ilki Üstad Ebu'l-Kasım diğeri Ali Ekber Isfahanî' dir. ${ }^{8}$

Foto. 1: Nakş-1 Cihan Meydan1

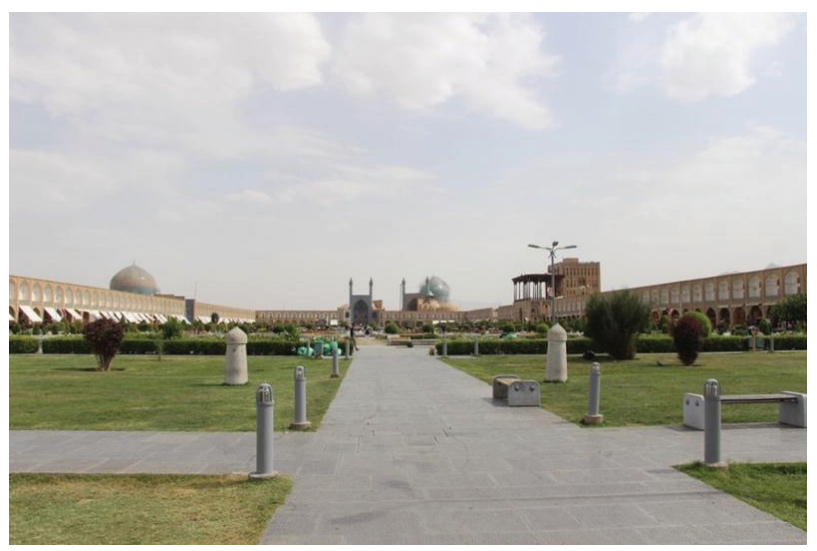

(Kaynağı belirtilmeyen fotoğraflar yazara aittir.)

6 Robert Hillenbrand, "Safavid Architecture", içinde The Cambridge History of Iran - The Timurid and Safavid Periods, VI, ed. Peter J. Jackson (Cambridge: Cambridge University Press, 1986), 775-776.

7 Arthur Upham Pope, "Safavid Period", içinde A Survey Of Persian Art, ed. Arthur Upham Pope (Tehran: Soroush Press, 1977), III, 1185; Lisa Golombek, “Anatomy of a Mosque: Masjed-e Shah in Isfahan", içinde Iranian Civilization and Culture, ed. Charles J. Adams (Montreal: McGill University Press, 1973), 5-15; Blair ve Bloom, "Safevi Dönemi Mimarisi”, 513.

8 Muhammed Yusuf Keyanî, İslam Dönemi İran Mimarisi (Ankara: İraniyat Yayınları, 2018), 77; Sheila R. Canby, The Golden Age of Persian Art (1501-1722) (London: The British Museum Press, 1999), 99-100; Beksaç, "Mescid-i Şah”, 291. 


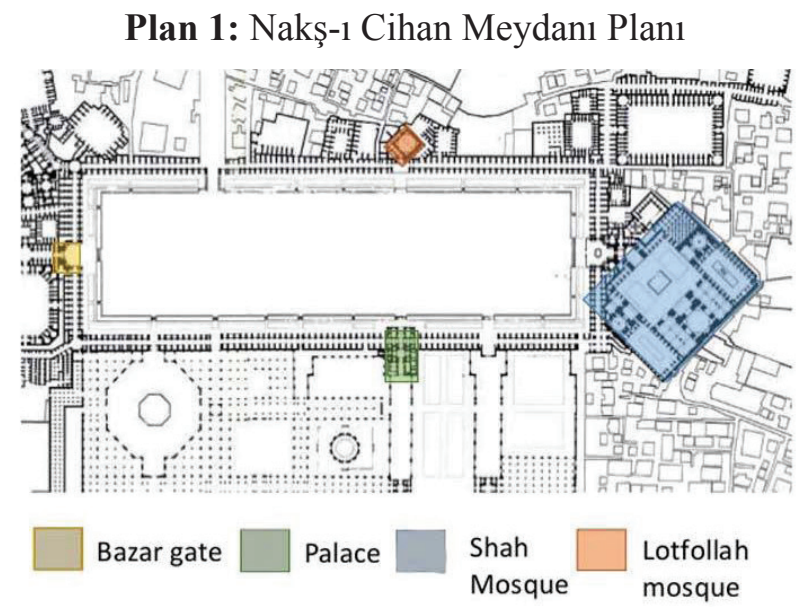

Kaynak: Son Erişim: 25 Kasım 2019,

https://irantourismer.com/naghsh-e-jahan-square-imam-square/

Mescid-i Şah, dört ayvanlı avlulu plan şemasının uygulanması bakımından Büyük Selçuklu Devri camilerinin devamı mahiyetinedir. Bununla birlikte yapıyı benzeri diğer örneklerden ayıran temel özelliklerden biri planının simetrik olmasıdır (Plan 2). Kubbe ile örtülü ana ibadet mekânının iki yanında ve yapıya bitişik olarak inşa edilmiş yan mekânlar mevcuttur. Bu birimler avluda namaz kılmanın elverişli olmadığı hava koşullarında namaz kılmak için ayrılan ilave bölümlerdir (Foto.3-4). ${ }^{9}$ Çalışmaya konu olan hayvan tasvirli çini pano, ana ibadet mekânına güneydoğudan bitişik olan söz konusu kışlık namaz bölmesinde yer almaktadır (Foto.5). Bahsi geçen birim aynı zamanda harem dairesi anlamına gelen şebistan kavramıyla isimlendirilmektedir. ${ }^{10} \mathrm{Bu}$ isimlendirme, birimin namaz kılmaya mahsus harem olarak kullanıldığının başka bir kanıtı mahiyetindedir.

Blair ve Bloom, "Safevi Dönemi Mimarisi”, 513.

10 Keyanî, İslam Dönemi İran Mimarisi, 78.; Burckhardt, İslam Sanatı, 199. 
Foto. 2: Isfahan Mescid-i Şah

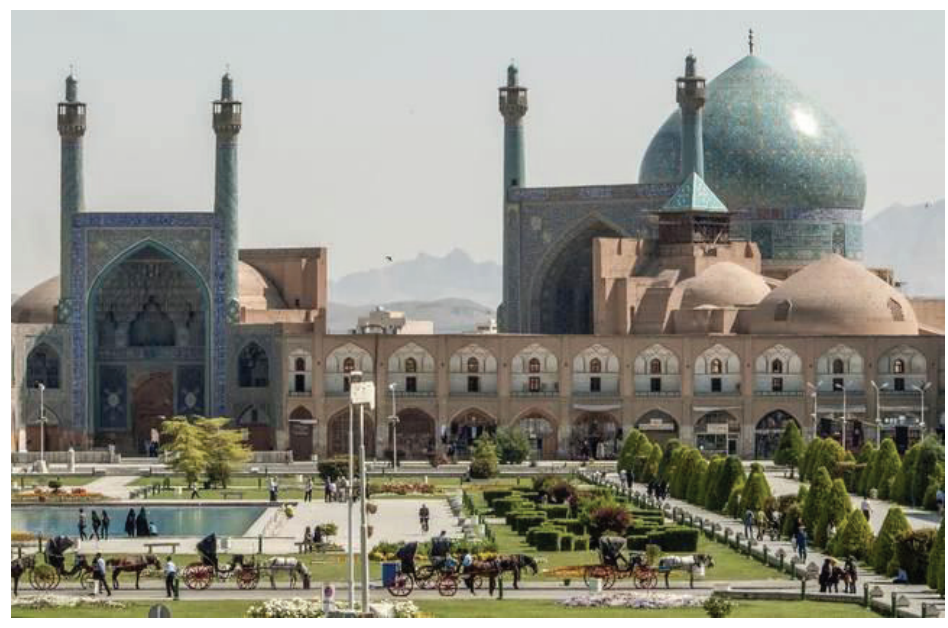

Kaynak: Son Erişim: 12 Aralık 2019, https://archnet.org/sites/1622/media_contents/119947

Plan 2: Isfahan Mescid-i Şah Planı

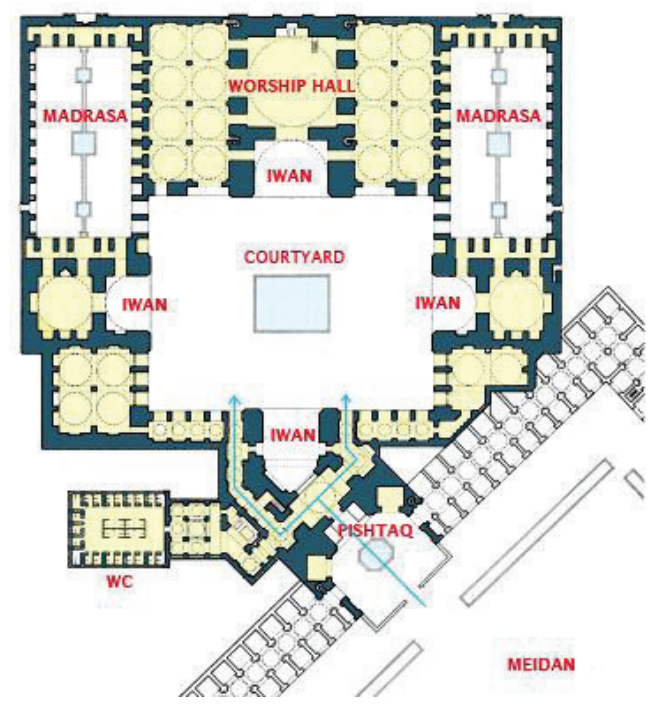

Kaynak: Son Erişim: 25 Kasım 2019,

http://www.ne.jp/asahi/arc/ind/2_meisaku/55_shah/sha_eng.htm 
Foto. 3: Isfahan Mescid-i Şah Ana İbadet Mekânı (Harem)

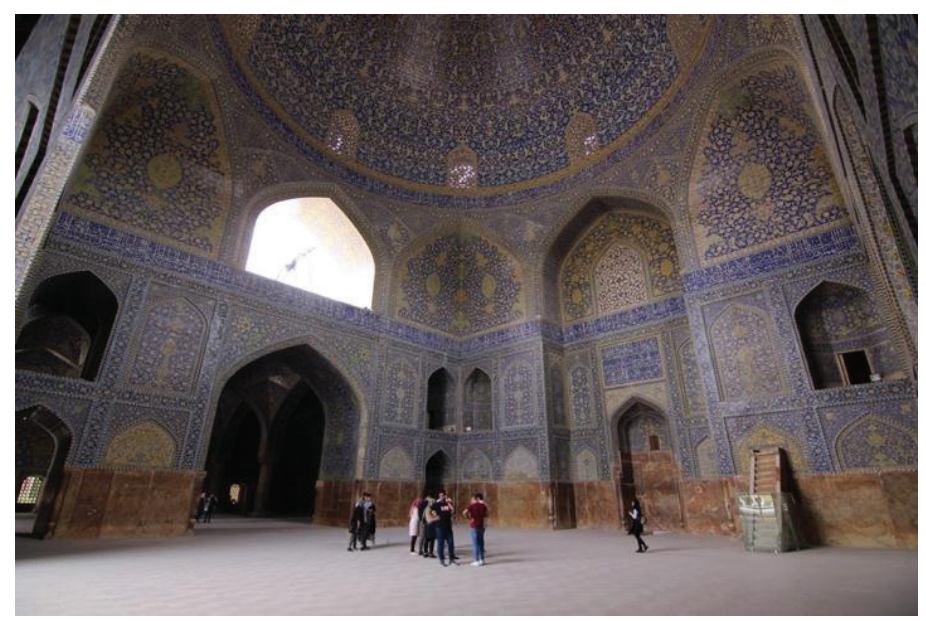

Foto. 4: Isfahan Mescid-i Şah Yan İbadet Mekânları (Şebistan)

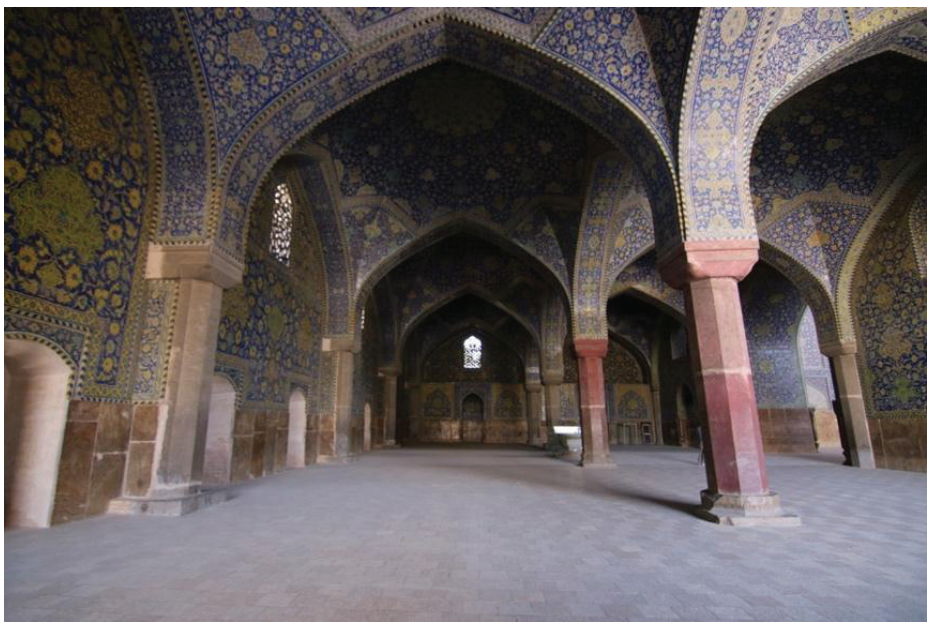

\subsection{Tezyînî Özellikleri}

Mescid-i Şah, İran'daki diğer birçok mimarî eser gibi tezyînî açıdan oldukça görkemli ve gösterişli bir yapıya sahiptir. Bu sebeple çalışmanın esas konusu olan hayvan tasvirli çini panonun detaylarına geçmeden evvel caminin genel tezyînî özellikleri hakkında bilgi vermenin yerinde olacağ kanaatindeyiz. 
İran'da Timurlulardan itibaren yaygın olarak görülmeye başlanan, yapıların iç ve dış cephelerinin çini ile kaplanmak sûretiyle bezenmesi Safevîler döneminde de devam etmiştir. ${ }^{11}$ Bunun en göz alıcı örneklerinden biri olan Mescid-i Şah'ın da neredeyse tüm yüzeyleri ve mimarî unsurları çini ile kaplıdır. Buna mukabil mihrap ve minberde mermer malzeme tercih edilmiştir (Foto.6). Ayrıca mihrabın kavsara kısmı yine çini ile bezenmiştir. Yapının hâkim süsleme unsuru olan çini, değişik birimlerde birbirinden farklı tekniklerle ele alınmıştır. Bu teknikleri kâşigeri (çini mozaik), heft reng ve sırlı tuğla şeklinde sıralamak mümkündür. ${ }^{12}$ Esasen yapıya yöneltilen en temel eleştiri bu hususta olmuştur. Zira Timurlu dönemine ait erken örneklerin aksine, çini mozaik sınırlı bir alanda uygulanmıştır. Onun yerine ucuz bir alternatif olarak tercih edilen heft reng tekniğinde imal edilen çiniler kullanılmış olup bunlarda da yüksek bir kalite elde edilemediği ileri sürülmektedir. ${ }^{13}$

Foto. 5: Isfahan Mescid-i Şah'ın Şebistan Biriminde Yer Alan "Yaban Hayvan Tasvirli Çini Pano"

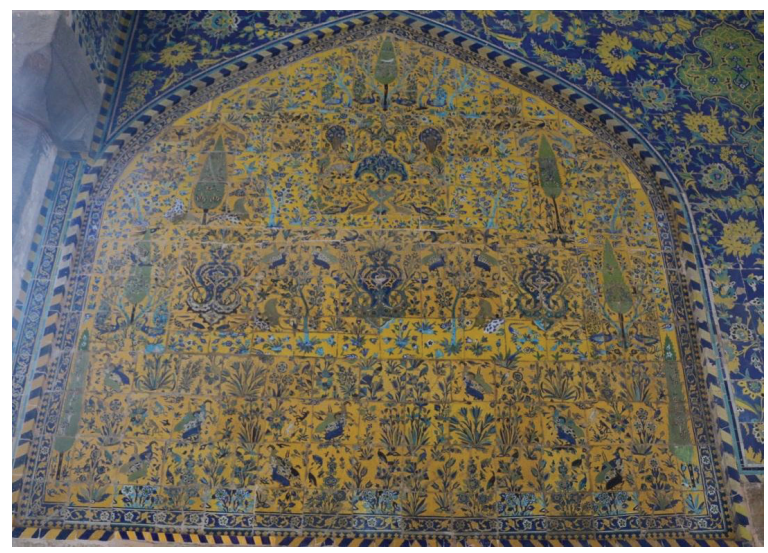

11 Şerare Yetkin, "Çini”, DİA, (İstanbul: TDV Yayınları, 1993), VIII: 329.,Aziz Doğanay, "Çini", içinde İslam Sanatları Tarihi, ed. Muhittin Serin (Eskişehir: Anadolu Üniversitesi Yayınları, 2010), 174.

12 Ali Reza Khajegir, Mohammad Reza Afroogh ve Ali Reza Fahim, "The Art of Islamic Architecture during the Safavid Period and the Introduction of the Teachings of Islam", Journal of Fine Arts 1, no. 3 (2018): 38, Son Erişim: 23 Mart 2019, https://www. sryahwapublications.com/journal-of-fine-arts/pdf/v1-i3/5.pdf.

13 Bernard O'Kane, Studies in Persian Art and Architecture, (Cairo: The American University in Cairo Press, 1995), 128; Hillenbrand, "Safavid Architecture", 788. 
Foto. 6: Isfahan Mescid-i Şah Ana İbadet Mekânında Yer Alan Mermer Mihrap ve Minber

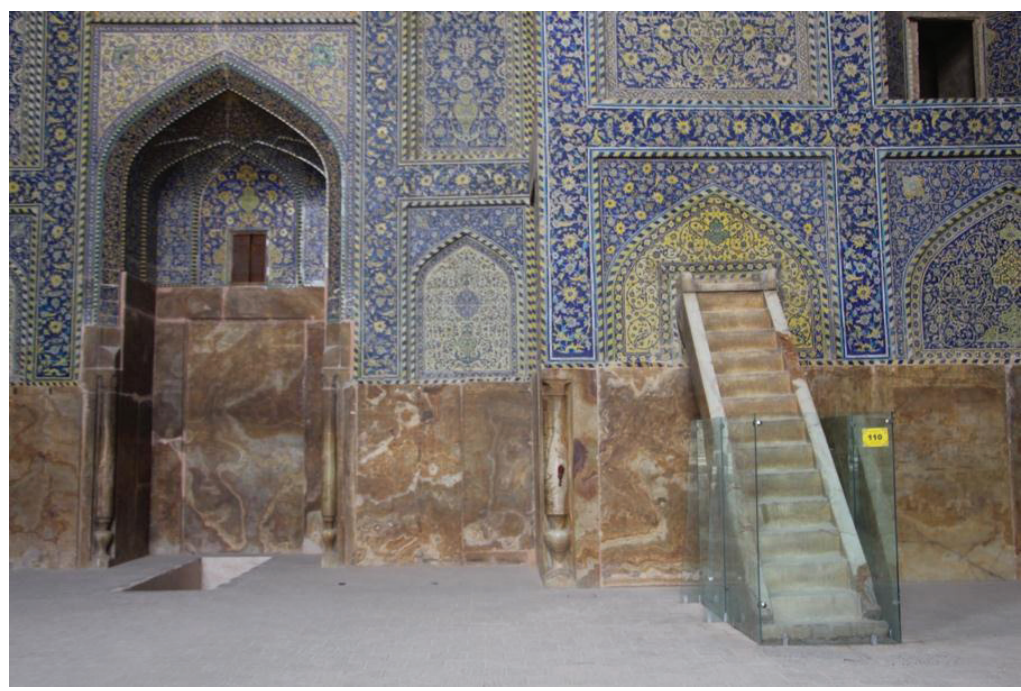

Caminin tezyînî açıdan en dikkati çeken birimi meydana açılan taç kapıs1dır. Taç kapı ve mukarnaslarında kâş̧igeri olarak adlandırılan çini mozaik tekniği uygulanmıştır. ${ }^{14}$ Taç kapıda bitkisel kökenli bezemelerin arasında figüratif bir süsleme mevcuttur. Bu süsleme karşılıklı iki tavus kuşu motifi şeklindedir. Tavus kuşları ortalarında yer alan ve içerisinden çiçekler çıkan bir vazoya dönük olarak tasvir edilmiştir (Foto.7).

14 Mohsen Alimorady ve Rahimnia Iman, "Seyr-i Tahhavvul-i Kâşikâri-yi ez Devrâni Sefeviye tâ Kâcâr bâ Berresi-yi Târihî Kâşikâri-yi Dâhilî-yi Mescid-i İmâm İsfehân”, Sevvomîn Humâyiş-i Millî'yi Mi'mâri-yi Dâhili-yi ve Dekorasyon, Muessese-i Âmuzeş-i Âlî Âzâd Dâniş Pejûhân, 1392, 5-10, Son Erişim: 13 Şubat 2020, https:// www.researchgate.net/publication/299430060_syr_thwl_kashykary_az_dwran_ sfwyh_ta_qajar_ba_brrsy_tarykhy_kashykary_dakhly_msjd_amam_asfhāan. 
Foto. 7: Isfahan Mescid-i Şah Taç Kapı Mukarnasında Yer Alan Karşılıklı İki Tavus Kuşu Figürü

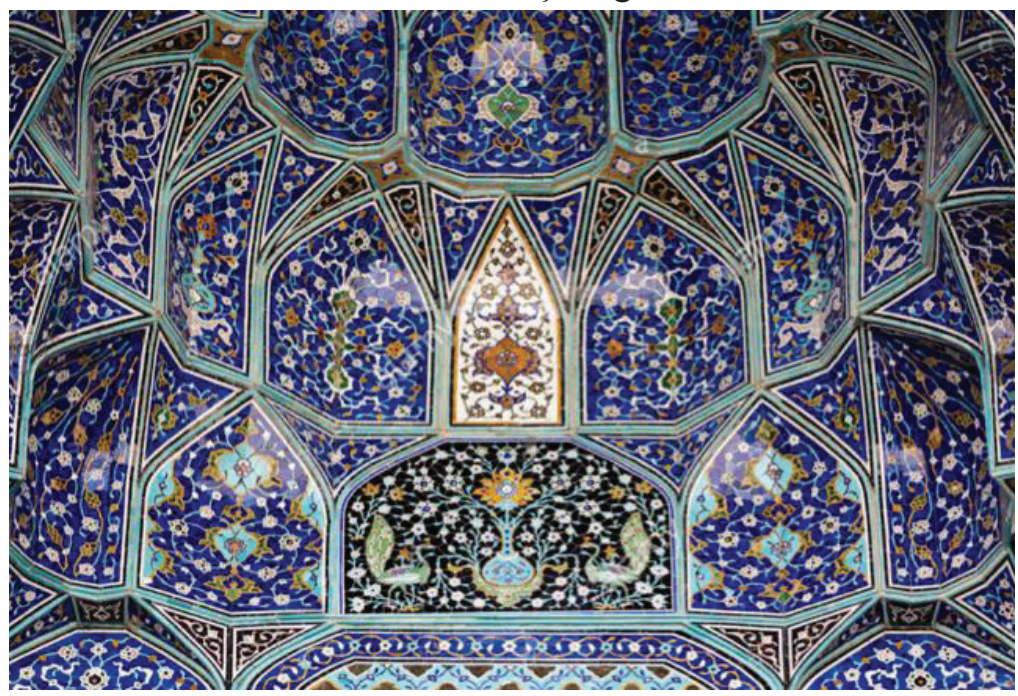

Kaynak: Son Erişim: 10 Nisan 2019,

https://www.alamy.com/detail-of-tile-work-entrance-portal-of-the-masjid-i-shahisfahan-iran-image62671142.html

Taç kapıda, giriş ayvanında ve mukarnaslarda uygulanan kâşigeri tekniği ışı̆̆ı çok iyi yansıtması bakımından oldukça gösterişlidir. Ancak yukarıda ifade edildiği üzere zahmetli ve maliyetli oluşu nedeniyle yapının tümünde uygulanmamıştır. Bununla birlikte bilhassa iç yüzeylerde çok renkli bir sırlama tekniği olan heft reng çinileri kullanılmıştır. ${ }^{15}$ Burada anlatılan tekniğin Osmanlı çini sanatında lâkabî tekniğine tekabül ettiğini düşünmekteyiz. ${ }^{16}$ Kimi yabanc1 kaynaklarda heft reng tekniği, cuerda seca ${ }^{17}$ kavramıyla ifade edilmesine karşın İspanyolların kullandığı cuerda seca ile İslam sanatında kullanılan heft reng birbirinden farklı özelliklere sahip iki ayrı tekniktir. ${ }^{18}$ Yapıda bezeme unsurlarının nakşedildiği malzeme olarak

\footnotetext{
15 Blair ve Bloom, “Safevi Dönemi Mimarisi”, 513;

16 Çini teknikleri için bkz. Aziz Doğanay, "Çini”, içinde İslâm Sanatları Tarihi, ed. Muhittin Serin (Eskişehir: Anadolu Üniversitesi Yayınları, 2010), 170-193.

17 Blair ve Bloom, "Safevi Dönemi Mimarisi”, 513;

18 Parviz Holakooei, "Technological study of the seventeenth century haft rang tiles in
} 
çini dışında mermer, ahşap ve alçı kullanılmıştır. Bezemede tercih edilen motifler ise rûmî (islîmî) ${ }^{19}$, hatâyî, hendesî, nebatî, ve figüratif unsurlar şeklinde sıralanabilmektedir. Ayrıca cami tezyînâtında sülüs yazı çeşidi ağırlıkta olmak üzere birçok hat kompozisyonu mevcuttur. ${ }^{20}$ Camideki kitabelerin hattatları Ali Rıza Abbasî, Muhammed Rıza İmamî, Muhammed Salih Isfahanî' dir. ${ }^{21}$

Yapıda nakkaş imzası bulunmamaktadır. Bununla birlikte dönemin en meşhur hattatı olarak bilinen Ali Rıza Abbasî, hattatlığının yanı sıra müzehhip ve musavvirdir. Zira kendisine atfedilen tezhipli ve minyatürlü yazmalar bulunmaktadır. ${ }^{22}$ Ayrıca Ali Rıza Abbasî, I. Abbas'ın Isfahan'da kurduğu ve saraya bağl1 faaliyet gösteren kitâbhâne denilen nakkaşhanesinin başındaki usta sanatkârdır. ${ }^{23}$ Ancak yapıda kitabeler haricindeki tezyînî unsurlarda bir dahli olup olmadığı bilinmemektedir.

\section{Hayvan Tasvirli Çini Pano ve Üslûp Özellikleri}

\section{1. Üslûp Özellikleri}

Hayvan tasvirli çini pano, Mescid-i Şah'ın kubbeli ana ibadet mekânına güneydoğudan bitişik olan kışlık namaz bölümünün (şebistan) kuzey duvarında yer almaktadır. Kemerli niş görünümündeki pano simetrik bir ta-

Iran with a comparative view to the cuerda seca tiles in Spain" (Doktora Tezi, Università degli Studi di Ferrara, 2013), 104-105, Son Erişim: 16 Mayıs 2019, http://eprints.unife. it/780/1/PhD\%20Thesis_Holakooei_PDFA.pdf; Doğanay, "Çini”, 185-186.

19 İslîmî; rûmî ya da hatayî gibi sap üzerinde yürüyen, nebatî karakterli süslemelere Farisîlerce verilen ad. Kaynaklarda kesinlik arz etmemekle birlikte rûmî nakışına verilen isim. Bkz. Aziz Doğanay, Osmanlı Tezyinatı-Klasik Devir Osmanlı Hanedan Türbeleri (1522-1604) (İstanbul: Klasik Yayınları, 2009), 81, 82, 424.

20 Elham Parvazi ve Hassanali Pourmand, "Tecelli-yi "Âlem-i Misâl der Tezyînât-i Mi'mâri-yi Asr-i Safevî (Numûne-i Movrid-i: Mescid-i İmâm İsfahân)”, Ârmânshahr Journal - Architecture and Urban Development 5, no. 9 (1391/2013): 34, 39-4, Son Erişim: 15 Nisan 2019, http://www.armanshahrjournal.com/article_33206_4b6246f5c c24524f471d3887c9762417.pdf.

21 Keyanî, İslam Dönemi Irran Mimarisi, 77; Pope, "Safavid Period", 1185; Hillenbrand, "Safavid Architecture", 786-787.

22 Isabel Hubbard, "Ali Rıza-i Abbasî, Calligrapher and Painter”, Ars Islamica, no. 4 (1937): 284, Son Erişim: 1 Nisan 2019, https://www.jstor.org/stable/25167043; Zeren Tanınd, “Topkapı Sarayı Kitap Hazinesi’nin Nadide Eserlerinden Bir Diğeri: Hazine 2166 Numaralı Safevî Albümü Hakkında”, Sanat Tarihi Yıllığı, no. 25 (2016): 198.

23 Tanınd1, “Topkapı Saray1 Kitap Hazinesi...”, 197. 
sarıma sahiptir. Sarı zemin üzerinde koyu yeşil servi ağaçları, kır çiçekleri, lâleler, yaprakları çiçeğe durmuş birbirinden farklı ağaç türleri, bezemeli vazolar içerisinden yükselen çiçek demetleri ve bulut kümelerinin resmedildiği panoda bilhassa yaban hayvanlarının tasvir edilmiş olması dikkat çekicidir (Foto.5).

Çini panoda tasvir edilen hayvanları yusufçuk, kelebek, kaplumbağa, tavus kuşu, keklik, sülün, balıkçıl, ördek, arı kuşu, karabatak, leylek, kaz, sırtlan, kaplan, aslan, geyik, dağ keçisi ve maymun şeklinde sıralamak mümkündür. Aslan ve kaplanlardan birkaçı avlanır halde tasvir edilmiştir. Tam simetrik olmamakla birlikte karşılıklı resmedilen maymun çiftlerinden altta olanlarının elinde karaak adı verilen birer şarap şişesi görülmektedir (Foto.8-9).

Foto. 8: Yaban Hayvan Tasvirli Çini Panodan Detay I

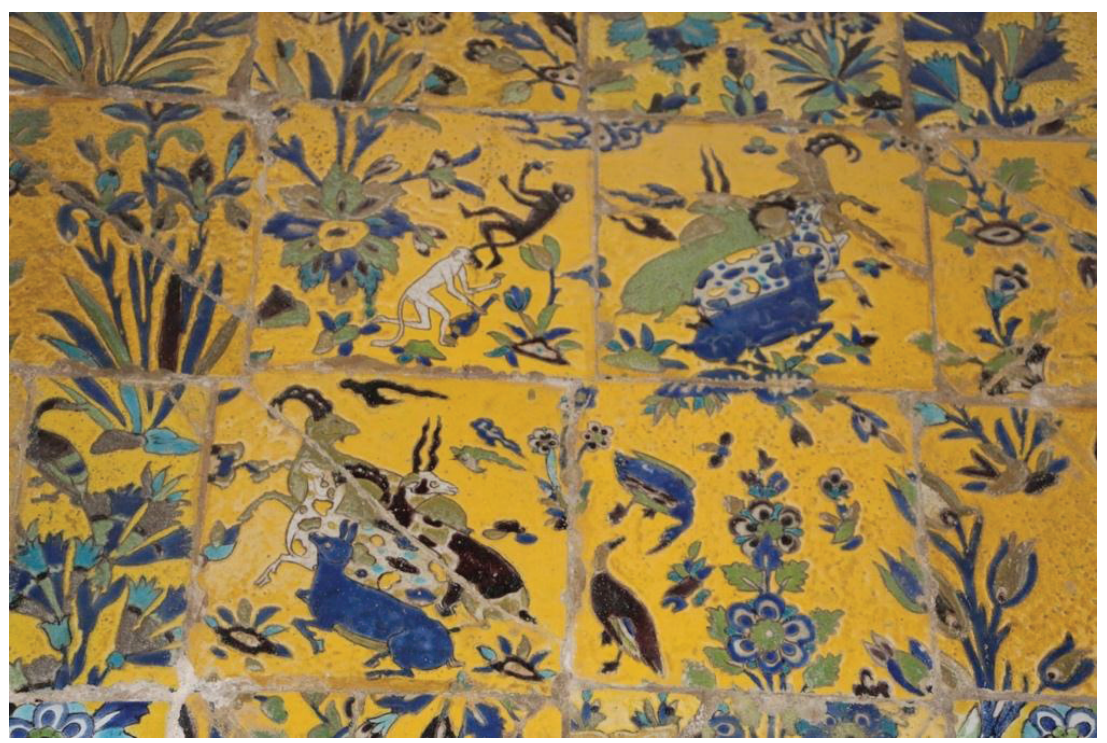


Foto. 9: Yaban Hayvan Tasvirli Çini Panodan Detay II

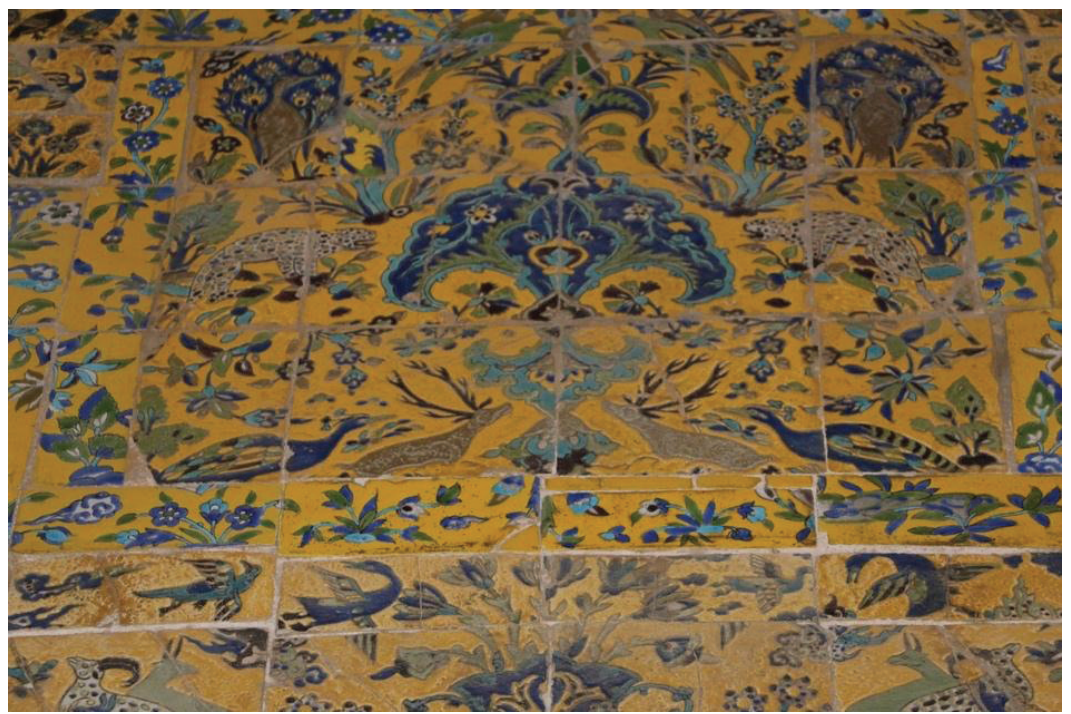

Daha önce ifade edildiği üzere İslam sanatında dînî mimarîde figüratif bezemeden mümkün olduğunca kaçınıldığı bilinen bir gerçektir. Her ne kadar sivil mimarîde, medreselerde, türbe yapılarında ve saraylarda canlı tasvirine yer verilse de dînî mimarîde bu tür örnekler oldukça nadirdir. Bununla birlikte Safevîler, tıpkı Anadolu Selçukluları gibi mimarîde figüratif unsurlar kullanma hususunda diğer İslam devletlerine kıyasla daha esnek davranmışlardır. ${ }^{24}$

Anadolu Selçuklularında ve Beylikler döneminde cami mimarîsinde karşımıza çıkan figürlü bezemeler genellikle yapıların taç kapısında veya dış cephelerinde yer almaktadır. Benzer şekilde Mescid-i Şah'ın giriş ayvanında da ziyaretçileri karşı1ıklı iki tavus kuşu karşılamaktadır (Foto.7). Ancak hayvan tasvirli çini pano, yapının ibadete mahsus biriminde yer alması sebebiyle diğer örneklerden ayrılmaktadır. Bu durumun yanı sıra panonun daha önceki figürlü bezemelerden ayrı olarak hayli teferruatlı bir tasvire sahne olması, gerek üslûp gerekse anlam bakımından bir farklılaşmanın göstergesi niteliğindedir. Panoda resmedilen kompozisyon, adeta minya-

24 O'Kane, Studies in Persian Art and Architecture, 128. 
türlü bir yazmadan yahut ipekli bir dokumadan aktarılmış hissi uyandırmaktadır. Nitekim Safevî dönemi saraylarının duvar resimlerinde bu etkileşim ortaya konulmuş ve halı desenleri ile duvar resimlerinin ustalarının büyük ihtimalle aynı ressamlar olduğu ileri sürülmüştür. ${ }^{25}$

Bununla birlikte yazma eser bilimi (codicology) verilerine göre XVI. yüzy1la tarihlenen albümlerin kenarlarında aks veya halkâr teknikleri kullanılarak meydana getirilen tasvirlerin hayvan tasvirli çini pano ile neredeyse aynı desen tasarımlarına sahip olduğu görülmektedir. Örneğin keçi, tilki, ördek ve ceylan yakalayan kaplan gibi çeşitli hayvanların tasvir edildiği, döneme ait yazmalarda sarı zemin üzerinde koyu renk ağaçların yer almas1, bahsi geçen pano ile renk kullanımının dahi aynı olduğunu gözler önüne sermektedir. Söz konusu yazmalar kitap sanatlarında "Isfahan üslûbu" şeklinde anılan ve I. Abbas'ın kurduğu nakkaşhaneden çıkmış yahut orada derlenmiş eserlerdir. ${ }^{26}$

Esasen yazmalardaki desen kompozisyonlarının mimarîye aktarılması şeklindeki bu uygulama I. Abbas döneminde ortaya çıkan sonrasında Zend ve Kaçar hanedanlıkları döneminde gelişme kaydeden yeni bir üslûbun ilk nüveleri olarak düşünülebilmektedir. Buna göre klasik yazmalarda yer alan tasvirler tuvallere, panolara ve tek sayfa resimler şeklinde çerçeveye aktarılmaya başlanmıştır. ${ }^{27}$ Böylece içerisinde yer aldığ 1 kitabın konusuna bağlı olarak ortaya konulan minyatür resimler, söz konusu uygulama ile başlı başına birer sanat eserine dönüştürülmek suretiyle yeni bir sanat anlayışının doğduğu söylenebilir. ${ }^{28}$ Bununla birlikte kapılar, duvarlar, panolar, kalem kutuları gibi farklı birim ve materyaller üzerinde bağımsız birer sa-

25 Reyhaneh Rashidi ve Shahryar Shokrpour, "The Study of the Influence of the Safavid Era Carpets on Animal Motifs in Murals of the Pirnia House", Journal of Faculty of Art Shahed University, no. 42 (2017): 98, Son Erişim: 6 Nisan 2019, http://negareh. shahed.ac.ir/article_532_1f85c12d31f396bd2e7b5be30a176a93.pdf.

26 Nazanin Davari ve Jamshid Hatam, "Safevi Döneminde Avrupa Tarzı Duvar Resimleri: Bir Sanat Tarihi Okuması”, Irran Çalışmaları Dergisi 2, no.1 (2018): 128-129.

27 Tanınd1, “Topkapı Sarayı Kitap Hazinesi...”, 191, 195 196, 206.

28 Tolga Uzun, “İran'da Öykülü Resimlerin Dolaşımı: İslam Edebiyatının Popüler Konularının El Yazmalardan Tuvallere Taşınması Üzerine Bir Deneme”, Modern Türklük Araştırmaları Dergisi 5, no. 2 (2008): 128-129; Hamit Arbaş, "Bir Minyatürden Hareketle Isfahan Okulu Ve Riza Abbasi”, Güzel Sanatlar Enstitüsü Dergisi, no. 25 (2011): 92, Son Erişim: 12 Nisan 2020, https://dergipark.org.tr/en/download/articlefile/28695; Bahman Razi Olyaei, "17. Yüzyll'da Avrupa Görsel Sanat Eserlerinin İran'1n Geleneksel Resmine Etkisi”, Sanat Tarihi Yıllı̆̆l, no. 27 (2018): 232-233. 
nat eseri hüviyetine bürünen sahnelerin yeni haliyle bir anlam içermediğini ileri sürmek mümkün değildir. Zira söz konusu kompozisyonlar yukarıda ifade edildiği gibi temelinde edebî ya da dînî metinlerin anlatıldığı bir yazma esere dayanmaktadır.

I. Şah Abbas döneminde ortaya çıkan bu yeni üslûp, Zend ve Kaçar hanedanlıkları döneminde Nizamî ve Camî gibi ünlü İranlı şairlerin klasik eserlerinden "Sultan Sencer ve Yaşlı Kadın", "Şirin 'in Ferhat'ı Ziyareti”, "Hüsrev ile Şirin”, "Varka ve Gülşah", "Yusufile Züleyhâ", "Behram Gur ve Âzâde" ve "Rüstem ile Ak Dev'in Mücadelesi" vb. sahnelerin mimarîde kullanılmak üzere dev tuvallere yahut çinilere aktarılmasıyla farklı bir boyut kazanmıştır (Foto.10-11-12). ${ }^{29}$

Foto. 10: Şiraz Kerim Han Zend Kalesi (18.yy) "Rüstem ile Ak Dev Mücadelesi"

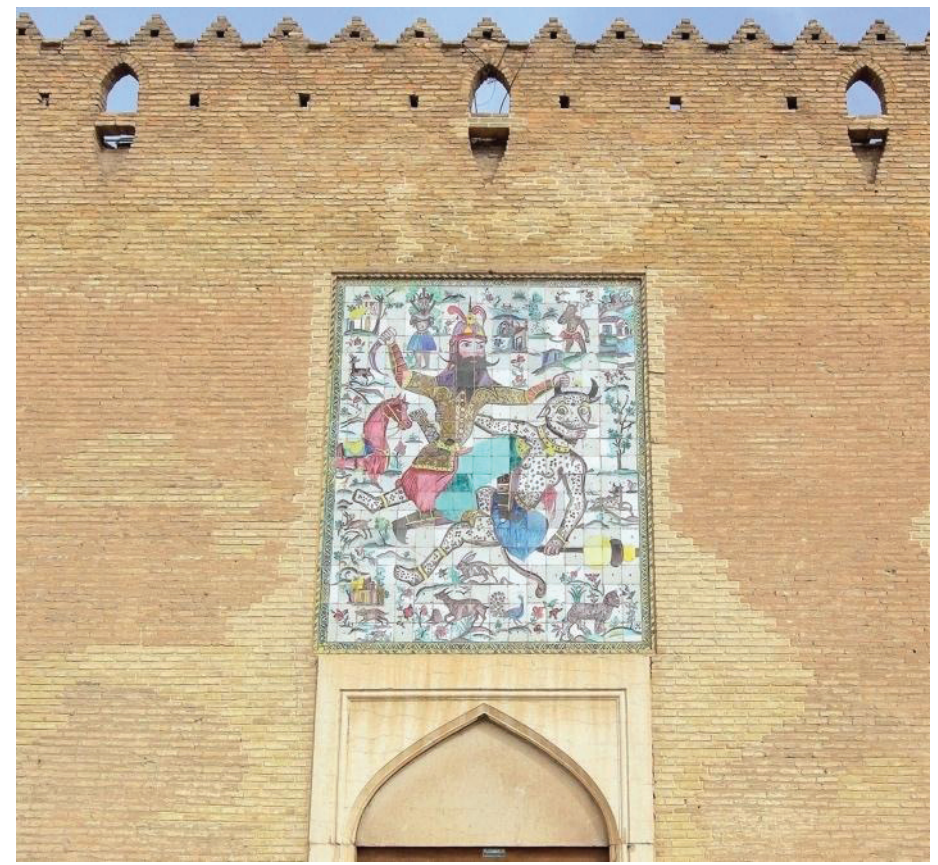

29 Uzun, “İran’da Öykülü Resimlerin Dolaşımı...”, 130, 135. 
Foto. 11: Şiraz İrem Bağları - Kaçar Dönemi Narencistan Sarayı'nda (19.yy) İran Mitolojisi ve Edebiyatından Sahneler

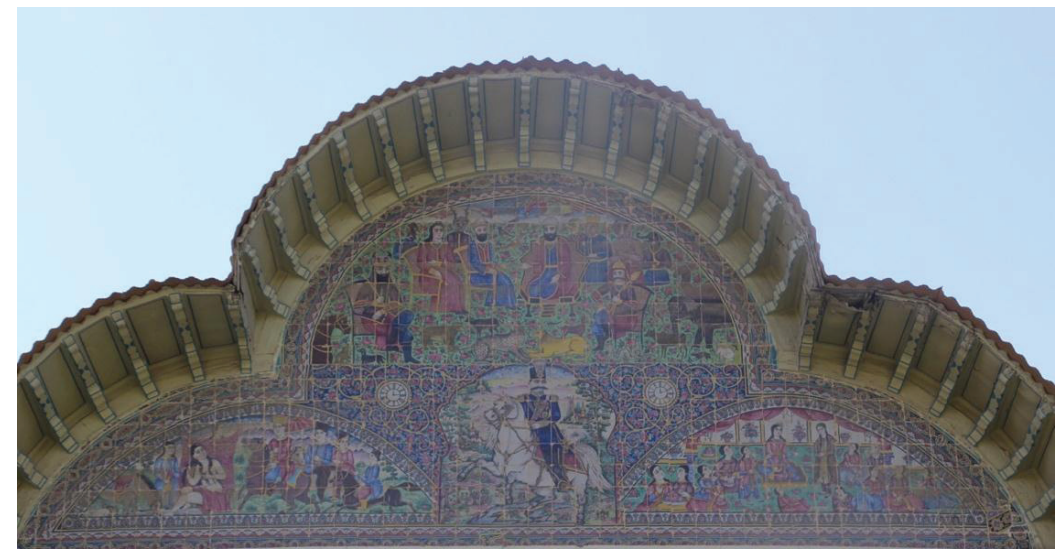

Kaynak: Sümeyra Ocak Arşivi

Foto. 12: Şiraz İrem Bağları - Kaçar Dönemi Narencistan Sarayı'nda "Behram-1 Gur Aslan Avında"

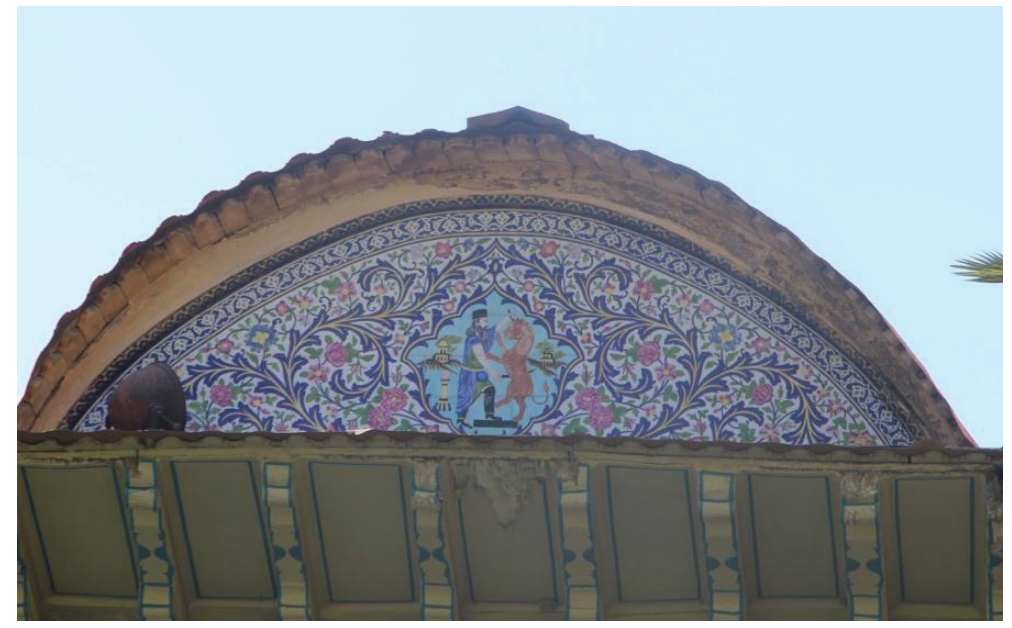

Kaynak: Sümeyra Ocak Arşivi

Bununla birlikte İslam öncesi Fars kültüründe benzer bir yaklaşımın varl1ğından söz edilebilir. Örneğin Persepolis'te yer alan taş kabartmalarda gerek Fars mitolojisi kahramanlarının gerekse dönemin hükümdarlarının ha- 
yatlarından sahnelerin taşa nakşedildiği görülmektedir. ${ }^{30}$ Ancak mimarîde neredeyse bir yazma eser kadar detaylandırılmış olan tasarımlar I. Şah Abbas döneminde görülmeye başlamıştır.

\section{2. Üslûbun Ortaya Çıkışına Etki Eden Faktörler}

Yukarıda ifade edilen üslûbun ortaya çıkışında birden çok faktör etkili olmuştur. İlk olarak Safevî yönetimi altında İran'ın kendine özgü bir İslam kültürü geliştirdiğini ifade etmek gerekmektedir. Devletin kurucusu Şah İsmail'in babası ve dedesi Türk ve Sünnî olmalarına karşın Safevî devletinin kurucu saikleri Şii ${ }^{31}$ ve Fârisî unsurları ön plana çıkarmak şeklinde cereyan etmiştir. ${ }^{32} \mathrm{Bu}$ yönelim beraberinde sanatta eski İran mirasını işlemeyi getirmiştir. ${ }^{33}$ Daha önce değinildiği üzere söz konusu yaklaşım Fars mitolojisinin tasviriyle bilhassa minyatürlü yazmalarda ve sivil mimarîde daha sonraki dönemlerde de kendini göstermektedir (Foto. 10-11-12).

Dönemin hükümdarı Şah I. Abbas ise Şii kimliğini öne çıkarmasının yanı sıra diğer zümrelere karşı hoşgörülü tavırlarıyla tanınmaktadır. Onun bu yönünün ticareti, iş hayatını ve sanatları bazı dînî kısıtlamalardan kurtar-

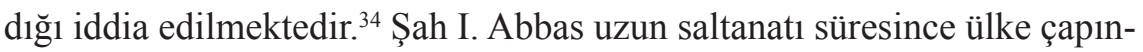
da kapsamlı imar ve bayındırlık faaliyetlerinde bulunmuştur. Ferahâbad gibi yeni kurduğu şehirlerin yanı sıra eski başkent Kazvin, Kâşân, Teb-

30 Detaylı bilgi için bkz. Aziz Hatami, Persepolis Pasargade and Naghsh-e-Rustem, (Tehran: The General Department of Publications and Broadcasting, t.y.).

$31 \quad$ N. Utaberta ve diğerleri, "The Study on the Development of Ornamentation in the Architecture of Safavid Dynasty", World Academy of Science, Engineering and Technology International Journal of Civil, Environmental, Structural, Construction and Architectural Engineering 6, no. 7 (2012): 466-467, Son Erişim: 19 Mayıs 2019, https://waset.org/publication/The-Study-on-the-Development-of-Ornamentation-inthe-Architecture-of-Safavid-Dynasty/1879; A. Damla Gürkan Anar, "Safevi Şahların Baniliği Üzerine Bir Değerlendirme”, Iran Çalışmaları Dergisi 1, no. 1 (2017): 120.

32 Detaylı bilgi için bkz. Sayın Dalkıran, “İran Safevî Devleti’nin Kuruluşuna Şii İnançların Etkisi ve Osmanlı'nın İran'a Bakışı”, Atatürk Üniversitesi İlahiyat Fakültesi Dergisi, no. 18 (2002): 55-102, Son Erişim: 10 Mart 2020, http://isamveri.org/pdfdrg/ D00018/2002_18/2002_18_DALKIRANS.pdf; Tufan Gündüz, "Safevîler", DİA, (İstanbul: TDV Yayınları, 2008), XXXV: 455.

33 Markus Hattstein, "İran Safeviler ve Kaçarlar", içinde İslam Sanatı ve Mimarisi, ed. Markus Hattstein ve Peter Delius (İstanbul: Literatür Yay., 2007), 496; Hillenbrand, Íslam Sanatı ve Mimarlığı, 233-234.

34 Hattstein, "İran Safeviler ve Kaçarlar”, 499. 
riz, Erdebil ve Meşhed şehirlerinde âbidevî eserlere bânîlik yapmıştır. ${ }^{35}$ Isfahan ise Şah I. Abbas döneminin en görkemli eserlerinin bulunduğu şehirdir. Şah Abbas, başkenti Kazvin'den Isfahan'a taşımasının ardından burada İslam devletlerinde görülmedik büyüklükte bir meydan oluşturmuş ve taç kapıları meydana açılacak şekilde üç âbidevî eser inşa ettirmiştir (Foto.1-Plan 1). ${ }^{36}$ Ayrıca meydanı çevreleyen dükkanların her biri zanaat ve sanat erbâbının atölyelerine dönüştürülmüştür. Buna ilaveten Âli Kapu Sarayı'nda kurduğu nakkaşhanede birçok sanatkârı himaye etmiştir. ${ }^{37}$ Şah Abbas'ın bu tavrı onun bir imparatorluk arayışı içerisinde olduğunu ortaya koymaktadır. Avrupa ile temasa önem vermesi, anıt eserler inşa ettirmesi, dönemin sanatta ve siyasette büyük güçleri İstanbul ve Delhi ile rekabet duygusu içerisinde olduğunun da göstergesidir. ${ }^{38}$

Hâlihazırda ticaret yolları üzerinde olan Isfahan, başkent olmasıyla diplomasinin de önemli bir merkezi haline gelmiştir. Avrupalı seyyâhlar bu şehre çok rağbet etmişlerdir. Böylece Avrupa ile etkileşim artmış ve Bat1lı sanat eğilimleri Isfahan'daki yeni sarayda görülmeye başlamıştır. ${ }^{39}$ Isfahan'da ortaya çıkan Avrupa modasının bir diğer sebebi ise yine Şah I. Abbas'ın siyasî ve ticarî gayelerle gerçekleştirdiği bir icraatıdır. Şah Abbas, Osmanlı'dan ve Türkmen aşiretlerinden gelebilecek tehlikeleri bertaraf etmek ve merkezî otoriteyi güçlendirmek maksadıyla ülkede toplu yer değiştirmeleri öngören bir strateji uygulamıştır. Bu kapsamda birçok Türkmen aşiretinin parçalanarak ülkenin farklı eyaletlerine göç ettirilmesiyle birlikte Yahudi, Gürcü ve Ermeni tebaanın da yerleri değiştirilmiştir. Nahcivan'ın Culfa bölgesinde yaşayan Ermeniler Isfahan'a göç ettirilmiş

35 Cihat Aydoğmuşoğlu, "SSah Abbas (1587-1629) Devrinde İran'da Sosyal ve Kültürel Hayat", Türk Dünyası İncelemeleri Dergisi 11, no. 2 (2011): 268-269, Son Erişim: 26 Şubat 2019, https://dergipark.org.tr/tr/download/article-file/406660; Anar, "Safevi Şahların Baniliği Üzerine Bir Değerlendirme”, 123,129.

36 Faruk Sümer, “Abbas I", DİA (İstanbul: TDV Yayınları, 1988) I, 19; N. Utaberta ve diğerleri, "The Study on the Development...", 466.

37 Davari ve Hatam, "Safevi Döneminde Avrupa Tarzı Duvar Resimleri...”, 125-126.

38 Hillenbrand, "Safavid Architecture", 821.

39 Uzun, "İran'da Öykülü Resimlerin Dolaşımı...", 128; N. Utaberta ve diğerleri, "The Study on the Development...", s. 467; Safevî sanatına Batı etkisi için bkz. Amy S. Landau, "European Religious Iconography in Safavid Iran: Decoration and Patronage of Meydani Bet'ghehem (Bethlehem of the Maydan)", içinde Iran And The World In The Safavid Age, ed. Willem Floor ve Edmund Herzig (London: I.B. Tauris Yayınları, 2015), 431. 
ve burada Yeni Culfa adıyla bir mahalle kurmuşlardır. ${ }^{40}$ Onlara vatandaşlık hakk1, dînî yaşamda özgürlük ve ticarî konularda geniş imtiyazlar vermiştir. ${ }^{41}$ Şah I. Abbas'ın dînî alandaki hoşgörüsü ve ruhânî konulardaki açık görüşlülüğğ ${ }^{42}$ Ermenilerin Isfahan'da özgür bir ortamda yerleşmelerini ve çoğu 1650'ye kadar tamamlanmış olan 30'a yakın kilise inşa etmelerini beraberinde getirmiştir. ${ }^{43} \mathrm{Bu}$ kiliselerin on üçü XX. yüzyıla ulaşmıştır. ${ }^{44}$

Görüldüğü üzere dokuma başta olmak üzere Batı ile ticareti ellerinde bulunduran Ermeniler, Isfahan'daki sanat çevrelerinde etkili olmuşlardır. Ermeni mahallesinde mukîm Hıristiyan hâmîler de Avrupalı eğilimlerin hızlanmasında etkin rol üstelenmişlerdir. ${ }^{45}$

\section{Hayvan Tasvirli Çini Pano - İslam Sanatı mı, Hıristiyan Sanatı mı?}

Şah I. Abbas döneminde Isfahan'da, geldikleri yere nispetle, Yeni Culfa bölgesine yerleştirilen Ermenilerin inşa ettikleri kiliseler, geleneksel Ermeni mimarîsinden ziyade Safevî tarzı yerel mimarî ögeleri ve teknikleri içermektedir. Örneğin bu dönemde inşa edilen kiliselerde soğan kubbe ve İran üslûbunda sivri kemer görülmektedir. Absidler, sivri kemer kullanımı ve bezeme motifleriyle adeta bir ayvanı çağrıştırmaktadır (Foto.13). Ayrıca Ermenistan'da yaygın olarak kullanılan taş yerine burada süslemede çini malzeme tercih edilmiştir. ${ }^{46}$

40 Aydoğmuşoğlu, "Şah Abbas...”, 263.; Olyaei, “17. Yüzy1l'da Avrupa Görsel Sanat Eserlerinin İran'1n Geleneksel Resmine Etkisi”, 228-229.

41 Canby, The Golden Age of Persian Art, 96.

42 Hattstein, "İran Safeviler ve Kaçarlar", 499.

43 Ayrıntılı bilgi için bkz. Armen Hakhnazarian, Nor Djulfa - The Churches of The Armenian, çev. N. Sohrabi, (Tehran: Ferhangestân Honar,1991); Armen Haghnazarian, "Julfa iv. Architecture and Painting", Encyclopaedia Iranica 15, no. 3 (2009): 238-240, Son Erişim: 14 Nisan 2020, http://www.iranicaonline.org/articles/julfa-iv-architectureand-painting.

44 John Carswell, New Julfa: The Armenian Churches and Other Buldings (Oxford: Clarendon Press, 1968), 19.

45 Uzun, "İran'da Öykülü Resimlerin Dolaşımı...", 128-129. Davari ve Hatam, "Safevi Döneminde Avrupa Tarzı Duvar Resimleri...”, 125-126.

46 Hillenbrand, "Safavid Architecture", 840; Amy S. Landau ve Theo Maarten Van Lint, "Armenian Merchant Patronage of New Julfa's Sacred Spaces", içinde Sacred Precincts: The Religious Architecture of Non-Muslim Communities across the Islamic World, ed. M. Gharipour (Leiden-Boston: Brill, 2015), 321-322, Son Erişim: 11 Nisan 2020, https://www.academia. edu/37913425/_Armenian_Merchant_Patronage_of_New_Julfa_s_Sacred_Spaces_. 
Foto. 13: Isfahan Yeni Culfa Bölgesinde Yer Alan Beytüllahim Kilisesi (17.yy) Absidi

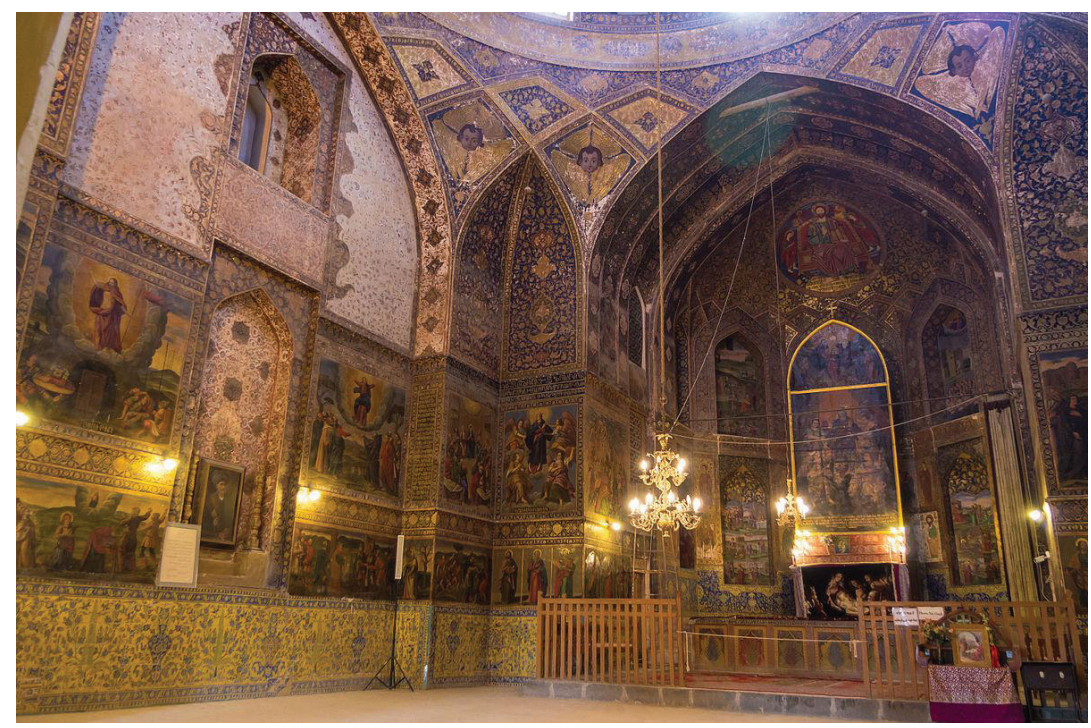

Kaynak: Son Erişim: 12 Ocak 2019, https://en.wikipedia.org/wiki/Bedkhem_ Church\#/media/File:Bedkhem_Church_09.jpg

Culfa'daki Ermeni kiliseleri süslemeleri bakımından ilginç özelliklere sahiptir. Bölgedeki kiliselerin birçoğu Ermeni, İran ve Avrupa stillerinde bir sentez sunan duvar resimleri ve desenler ile kaplıdır (Foto.14). ${ }^{47}$

47 Minoo Khakpour ve Fatemeh Kateb, “A Comparative Study of Religious Architecture in Christianity and Islam A Criticism of Titus Burckhardt's Theory (Case study: Isfahan)", Bagh- e Nazar 14, no. 50 (2017): 62, Son Erişim: 03 Mart 2019, https:// www.researchgate.net/publication/319006408_A_Comparative_Study_of_Religious_ Architecture_in_Christianity_and_Islam_A_Criticism_of_Titus_Burckhardt's Theory. 
Foto. 14: Isfahan Yeni Culfa Bölgesinde Yer Alan Vank Katedrali (17.yy)

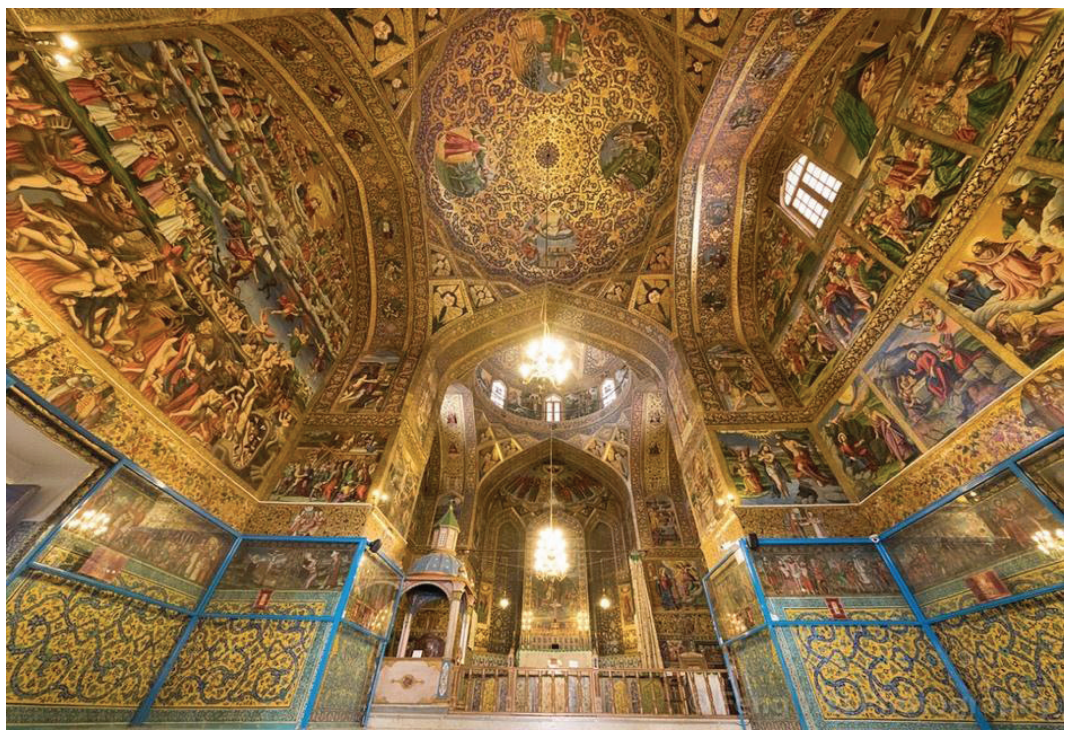

Kaynak: Son Erişim: 12 Ocak 2019

https://www.flickr.com/photos/fengwei888/40102133471

Burada çalışmamız açısından dikkati çeken husus ise makalemize konu olan hayvan tasvirli çini panonun teknik, üslûp ve motif bakımından çok benzer örneklerinin Yeni Culfa bölgesindeki beş kilisede mevcut olmasıdır. Bu kiliseler Kurtarıc1-Vank Katedrali (All Saviour's Cathedral-1662-3), Tanrı'nın Kutsal Annesi Kilisesi (The Church of The Holy Mother Of God-1612), Aziz Stefanos Kilisesi (St. Stephen Church-1613-14), Beytüllahim Kilisesi (The Bethlehem Church-1627-8) ve Aziz Sargis Kilisesi (St. Sargis Church-1608-9)' dir. ${ }^{48}$ Esasen bölgede ayakta kalan on üç kilise de Hıristiyan bezeme unsurlarının yanı sıra İslam sanatına özgü motifleri bünyesinde barındırmaktadır. Ancak yukarıda sıralanan kiliseler çini bezemeleriyle diğerlerinden ayrılmaktadır (Foto.13-14-15). 
Foto. 15: Isfahan Yeni Culfa Bölgesinde Yer Alan Beytüllahim Kilisesi (17.yy) Duvar Çinileri

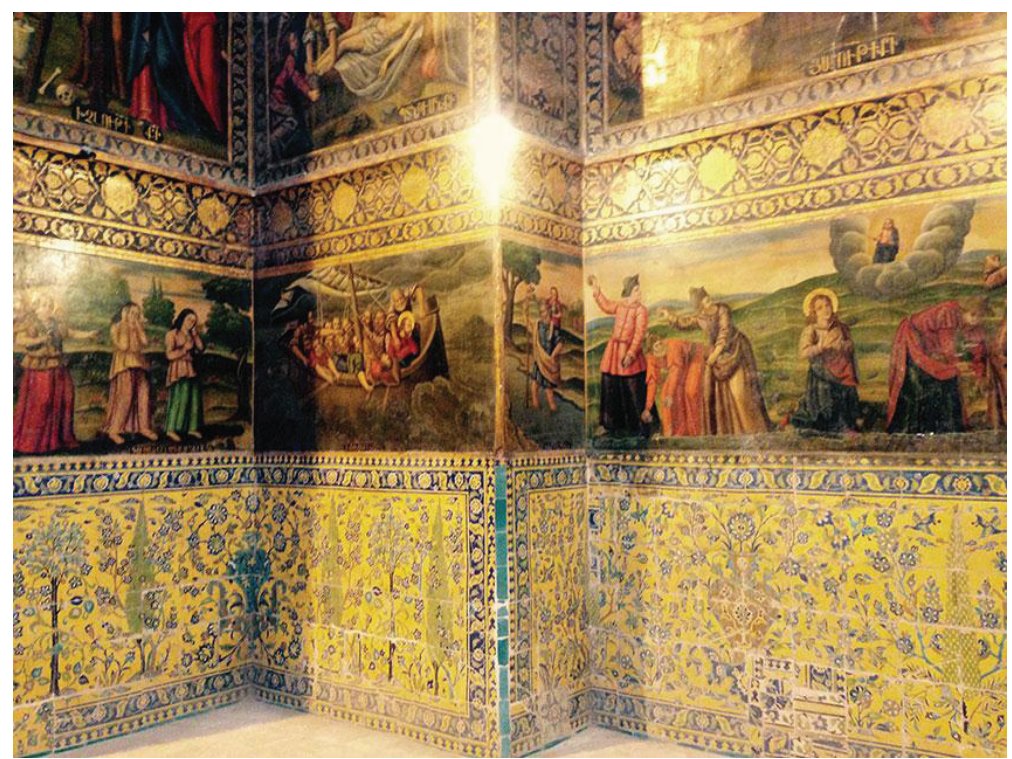

Kaynak: Son Erişim: 12 Ocak 2019,

http://www.iranicaonline.org/articles/julfa-iv-architecture-and-painting\#prettyPh oto[content $] / 5 /$

Eski ve Yeni Ahit'ten pasajların resmedildiği Vank Katedrali'nin kubbesinde kalem işi, duvarlarında ise yaklaşık bir metre yüksekliğe kadar çini üzerinde rûmî (islimî) motifleri tezyînâtta hatırı sayılır bir yüzeyi kaplamaktadır (Foto.14). Bu kilisede absidin ön kısmı kemerli niş şeklinde tasarlanmış çiniler ihtiva etmektedir. Absidin kenarları girland ve melek motifleri (Foto.16) içeren çinilerle çevrili olup kuzeydeki panele Ermenice bir kitabe metni işlenmiştir. 
Foto. 16: Isfahan Yeni Culfa Bölgesinde Yer Alan Vank Katedrali (17.yy) Absidinde Çini Üzerinde Melek Motifi

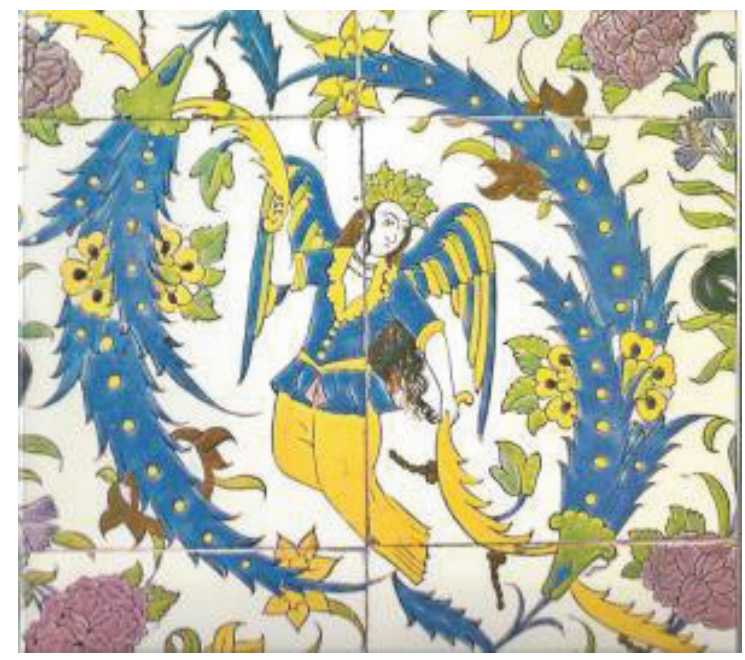

Kaynak: Son Erişim: 12 Ocak 2019,

https://www.abebooks.com/collections/sc/religion/4vV9XXaka T6GbAFYIGyExZ

Tanrı'nın Kutsal Annesi Kilisesi'nde yer alan çini panoların tasarımı Mescid-i Şah'taki panoya oldukça yakındır. Hayli fantastik bir kurguya sahip panelde kuşlar, çiçekler, gerçek ve hayali hayvanlar, vazolar ve servi ağaçları iç içedir. Hattâ kapının doğusunda bulunan çinilerde muhtemelen yapının banisi olduğu düşünülen diz çökmüş bir figür mevcuttur. Carswell'e göre buradaki çiniler, kendi türünde Culfa'daki en iyi örneklerdir. ${ }^{49}$

Konumuz dahilinde kısaca değineceğimiz bir diğer kilise Aziz Stefanos Kilisesi'dir. Culfa'da yaygın olarak karşımıza çıkan aynı üslûptaki heft reng çinilerine ilaveten kuzeybatı ve güneybatı payanda kaidelerinde mavi beyaz sır altı çinileri vardır. Ancak bunlar düşük kalitede ve renkleri birbirine geçmiş vaziyettedir. ${ }^{50}$

Yine aynı bölgede yer alan Beytüllahim Kilisesi çalışmamız açısından büyük önemi haizdir. Söz konusu kilisenin duvarları yerden bir metre yük-

49 Carswell, New Julfa .., 41.

50 Carswell, New Julfa..., 42-43. 
sekliğe kadar Mescid-i Şah’taki hayvan tasvirli çini pano ile malzeme, teknik ve üslûp açısından aynı özelliklere sahip çinilerle kaplıdır (Foto.1517). ${ }^{51}$ Mescid-i Şah'ta olduğu gibi heft reng tekniği ile çalışılan çinilerde işlenen desen ve figürler birkaç ayrıntı dışında neredeyse birebir örtüşmektedir. Sarı zemin üzerine mavi ve yeşil tonlarının kullanımının yanı sıra desenlerde tercih edilen servi ağaçları, vazo içinden çıan çiçekler, bulut motifleri, dağ keçileri ve kuş figürleri buradaki çini panolar ile Mescid-i Şah’taki panonun aynı atölyede üretildiklerini düşündürmektedir. Kiliselerdeki çinilerin bir özelliği de tıpkı Mescid-i Şah’ta olduğunu gibi niş yahut bordür şeklinde önceden belirlenmiş yerlere uyumlu olarak tasarlanmış olmalarıdır. $^{52}$

Foto. 17: Isfahan Yeni Culfa Bölgesinde Yer Alan Beytüllahim Kilisesi (17.yy) Duvar Çinilerinden Detay

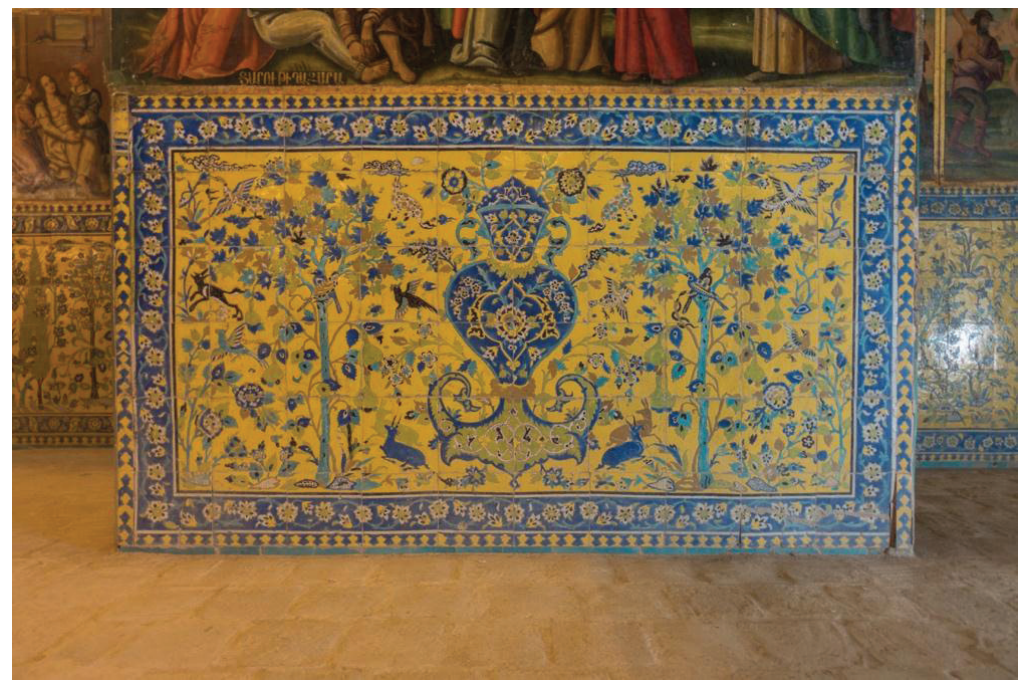

Kaynak: Son Erişim: 12 Ocak 2019, http://justinandcrystal.com/CentralAsia/CentralAsia-124.jpg

51 Holakooei, "Technological study of the seventeenth...", 20.

52 Carswell, New Julfa..., 26-27. 
Mimarî ve tezyînî açıdan oldukça ilginç bir sentez sunan Yeni Culfa bölgesi, Pers-Ermeni mimarîsinin yerel ve lokal bir okulu olarak görülmektedir. Burada Safevî estetiğinin yabancı bir gelenek üzerindeki serbest etkisi açıkça gözlemlenebilmektedir. ${ }^{53}$ Bazı yazarlar bu örnekleri İran ve Ermeni sanatının zarif bir uzlaşması olarak görmüştür. ${ }^{54}$ Carswell, Culfa bölgesindeki çinilerin geleneksel Pers esintisi ile Uzakdoğu etkisini birlikte barındırdıklarını ifade etmektedir. Bu görüşünü bulut, ejderha ve Anka kuşlarının tasarımlarda sıkça görülmesi ve kimi panoların ortasında temel motif olarak mavi beyaz Çin porseleninden vazoların resmedilmiş olmasıyla temellendirmiş̧ir. Ayrıca bu motiflerin XVII. yüzyılda Çin'den getirilen ve İran seramiklerini hayli etkileyen Çin porselenlerinden alınmış olabileceğini öne sürmektedir. ${ }^{55} \mathrm{Bu}$ iddia geçerli olabileceği gibi bulut, ejderha ve Anka kuşu motiflerinin İran'da çok daha eski dönemlerdeki yazmalarda kullanıldığını akıldan çıkarmamak gerekir. Kanaatimizce İran'da XVII. yüzyılda ortaya çıkan ve daha sonra bilhassa sivil mimarîde çeşitli örneklerle gelişen bu üslûbun, kilise tezyînâtında Yeni ve Eski Ahit kıssalarının resimlenerek ele alınması gibi, klasik İslam edebiyatı ve İslam öncesi Fars edebiyatının mimarîye yansımış şekli olduğunu ileri sürmek mümkündür.

Bir diğer önemli husus ise gerek camide gerekse kilisede görülen bu çinilerin ustalarının 'Müslüman mı yahut Hıristiyan mı?' olduğu sorusudur. Carswell, kiliselerdeki çinilerde bulunan Ermenice kitabelerden ve teknik açıdan işçiliğin iyi olmasına karşın figürlerin ele alınışının çok ilkel olmasından hareketle söz konusu çini duvar panolarının Ermeni ustaların elinden çıkmış olabileceğini ifade etmiştir. Zira ona göre figürlerin ilkel çizimleri, sanatçıların dini konuları betimlemek için bir araç olarak kullandıkları çinilere aşina olmadıklarının bir kanıtıdır. ${ }^{56}$

Ancak burada tasarımı yapan sanatçılar ile çiniye uygulayan ustalarının aynı olmama ihtimali göz ardı edilmektedir. Nitekim İslam sanatında süreç çoğunlukla nakkaşların ve hattatların tasarımları hazırlaması ve çini, taş ya da ahşap ustalarının bu tasarımları malzemeye aktarması şeklinde gerçekleşmiştir. Benzer durum Ermenice kitabeler için de gayet tabi

\footnotetext{
53 Hillenbrand, "Safavid Architecture", 774; Khakpour - Kateb, "A Comperative Study...", 68.

54 Halakooei, “Technological study of the seventeenth...", 20.

55 Carswell, New Julfa..., 26.

56 Carswell, New Julfa..., 26-27.
} 
mümkün olabilir. Ayrıca figürlerde Carswell'in 'ilkellik' olarak ifade ettiği özelliğin, sanatçıların çiniye âşinâ olmamasından ziyade İslam sanatındaki üslûplaştırma eğiliminden kaynaklanmış olduğu düşünülebilir. Bununla birlikte Isfahan'da saraya bağlı nakkaşhanede Avrupalı, Ermeni ve Hintli sanatçıların çalıştıkları bilgisi çeşitli kaynaklarda yer almaktadır. ${ }^{57}$

\section{Sonuç}

Titus Burckhardt ve Gelenekselci Ekol'ün birçok temsilcisi İslam sanatı ve Hıristiyan sanatlarının ruhsal nitelik ve sanat üslûbu açısından oldukça ayrı olduğu görüşündedir. Bunun sebebi olarak İsa Mesih'e vurgu yapan H1ristiyan teolojisinin bir öğretici sanata ihtiyacı olduğundan figüratif sanat1 öncelemesi; İslam sanatının ise renk, şekil, içerik gibi görsel ve fiziksel unsurların kullanımında doğrudan bir ifade biçimi yerine dolaylı anlatımı yahut teşbihi ön plana çıkarması görülmektedir. ${ }^{58} \mathrm{Bu}$ ve benzeri görüşlerden hareketle Hıristiyan ve İslam sanatının karşılaştırmalı olarak ele alındığı çalışmaların çoğunda estetik anlatım ve görsel sanat bakımından bu iki dine ait sanat eserlerinin farklılı̆̆ vurgulanmaktadır. ${ }^{59}$ Oysa çalı̧̧mamızda ele alınan hayvan tasvirli çini panodan hareketle Mescid-i Şah ve Beytüllahim Kilisesi başta olmak üzere Culfa kiliselerinin, genellikle savunulagelen Doğu - Batı sanatı farklılaşmasında bir istisna durumunda olduklarını söylemek mümkündür.

Diğer İslam şehirlerindeki kiliselerden farklı olarak Culfa'daki kiliseler, mimarîde sivri kemer, soğan kubbe, tuğla malzeme; süslemede çini formları ve rûmî motifinin kullanımıyla İslam sanatına özgü unsurlarla dekore edilmiştir. ${ }^{60}$ Ermeni kiliselerindeki kalem işi rûmî (islîmî) motiflerinin yanı sıra çinilerdeki minyatür repertuarına benzer manzaralar Safevî etkisini gözler önüne sermektedir. Bu çiniler, Ermenice kitabeleri ve kimi kiliseler-

57 Davari ve Hatam, "Safevi Döneminde Avrupa Tarzı Duvar Resimleri...”, 130; Olyaei, “17. Yüzyıl'da Avrupa Görsel Sanat Eserlerinin İran'ın Geleneksel Resmine Etkisi”, 225.

58 Khakpour ve Kateb, “A Comparative Study...”, 58.

59 Sanaz Bavaghar ve Abolghasem Dadvar, "A Comparative Study of the Altar Design Content of the Jame Mosque and the Vank Church of Isfahan", International Journal of Applied Arts Studies 2, no. 2 (2017): 66, Son Erişim: 5 Nisan 2019, http://ijapas.org/ index.php/ijapas/article/view/112/18.

60 Holakooei, “Technological study of the seventeenth...", 17. 
de desenlere ilave edilen melek figürleri dışında Hıristiyanlığ çağrıştıran unsurlar taşımamaktadır.

Mimarî unsurlar ve malzemenin yanı sıra bölgedeki kiliselerde İslam sanatına özgü motif ve desenlerin kullanımı, Safevî etkisini açıç̧a pekiştiren bir mahiyettedir. Ancak Culfa kiliselerinde İslam sanatı tesirinin yanı sıra duvar resimlerinde XVII. yüzyıl Avrupa resim sanatının etkisi de göz ardı edilmemelidir. ${ }^{61}$ İki ayrı üslûbun bu denli harmanlanması ve Apostolik Ermenilerin ikonoklast olmasalar da kendi coğrafyalarında daha sade bir dekoru tercih etmeleri, söz konusu kiliseleri özgün ve alışılmamış yapmaktadir. $^{62}$

Buradan hareketle Isfahan özelinde Safevî ve Ermeni sanatı arasındaki etkileşimin karşılıklı olduğunu ileri sürmek yanlış olamayacaktır. Zira kiliselerde Batı etkisiyle kendini gösteren, Eski ve Yeni Ahit sahnelerinin çok büyük boyutlarda resmedilmesi, Safevî döneminde ve sonraki hanedanlıklarda saray ve konut mimarîsinde İslam ve Fars edebiyatından sahnelerin resmedilmesi şeklinde ortaya çıkmıştır. Bu uygulama İslam öncesi Fars mimarîsinde mitolojik kahramanların ve hükümdarların hayatlarından sahnelerin kabartma suretiyle taşa işlenmesi şeklinde mevcuttur. Bununla birlikte Culfa'daki kiliselerin etkisiyle mimarîde bu tür tasvirlerin yeniden popülerlik kazandığı söylenebilir. Zira Heşt Beheşt ve Çehel Sütun saraylarında şahların yabancı elçilerle görüşme sahnelerinin dev boyutlarda tasvir edilmesi, Zend ve Kaçar hanedanlıkları dönemlerinde ise kale ve saray mimarîsinde Fars mitolojisinden örneklerin işlenmesi yine bahsi geçen etkileşimin bir neticesi olarak görülmektedir. ${ }^{63}$

Dönemin İslam ve Hıristiyan mimarîsi eserleri, yapı düzeni ve süsleme özellikleri bakımından bir ekip çalışması olduğu izlenimi uyandırmaktadır. Hıristiyan ustalarla Müslüman ustaların birlikte çalışmış oldukları düşünülebilir. Nitekim Isfahan'daki saray nakkaşhanesinde farklı din ve milletten sanatkârların çalıştığı bilinmektedir. ${ }^{64}$

${ }^{61}$ Landau, "European Religious Iconography...”, 429-430.

62 Landau, "European Religious Iconography...”, 426.

63 Uzun, “İran'da Öykülü Resimlerin Dolaşımı...”, 128-129.; Landau, "European Religious Iconography...”, 440-441.

64 Davari ve Hatam, "Safevi Döneminde Avrupa Tarzı Duvar Resimleri...”, 130.; Olyaei, “17. Yüzyıl'da Avrupa Görsel Sanat Eserlerinin İran'1n Geleneksel Resmine Etkisi”, 225. 
Robert Hillenbrand, İran'daki Ermeni mimarlığı ve çini örneklerinin açıça Hıristiyanlığa ait ikonografik mesajlar vermesine mukabil üslûp olarak İran tarzını büyük bir serbestlikle kullanmasını, Safevî Devleti'nin dînî toleransının bir kanıtı olarak kabul etmektedir. ${ }^{65}$ Netice itibariyle sanat eserleri ve süslemeler, Ermenilerin Safevî döneminde kentin dokusuna uyum sağladıklarını ortaya koymaktadır. Ayrıca her iki yapı türünde de karşımıza çıkan çini panoların, din ve inanç farklılıklarına rağmen kültürel bütünleşmeyi ve dayanışmayı gösterdikleri yadsınamaz bir gerçektir. ${ }^{66}$

\section{Kaynakça}

Alimorady, Mohsen, ve Rahimnia Iman. "Seyr-i Tehvel-e Kâshikâri ez Devrâni Sefeviye tâ Kâcâr bâ Berresi-yi Târihî Kâshikâri Dâhilî Mesced-e Emâm Esfehân." Sevvomîn Humâyish-i Millîyi Mi'mâri Dâhili ve Dekorasyon (Muessese-i Âmuzeş-i Âli Âzâd Dâniş Pejûhân) (1392): 1-11. Son Erişim : 13 Nisan 2020. https://www.researchgate.net/publication/299430060_syr_thwl_kashykary_az_dwran_sfwyh_ta_qajar_ba_ brrsy_tarykhy_kashykary_dakhly_msjd_amam_asfhan.

Anar, A. Damla Gürkan. "Safevi Şahların Baniliği Üzerine Bir Değerlendirme." İran Çalışmaları Dergisi 1, no.1 (2017): 117-143.

Arbaş, Hamit. "Bir Minyatürden Hareketle Isfahan Okulu ve Riza Abbasi." Güzel Sanatlar Enstitüsü Dergisi, no. 25 (2011): 85-97. Son Erişim: 12 Nisan 2020. https://dergipark.org.tr/en/download/article-file/28695.

Aydoğmuşoğlu, Cihat. "Şah Abbas (1587-1629) Devrinde İran'da Sosyal ve Kültürel Hayat.” Türk Dünyası Incelemeleri Dergisi 11, no. 2 (2011): 261-2716. Son Erişim: 26 Şubat 2019. https://dergipark.org.tr/tr/download/article-file/406660.

Bavaghar, Sanaz, ve Abolghasem Dadvar. "A Comparative Study of the Altar Design Content of the Jame Mosque and the Vank Church of Isfahan." International Journal of Applied Arts Studies 2, no. 2 (2017): 6168. Son Erişim: 5 Eylül 2019. http://ijapas.org/index.php/ijapas/article/ view/112/18.

\footnotetext{
65 Hillenbrand, İslam Sanatı ve Mimarliğl, 262.

66 Khakpour ve Kateb, “A Comparative Study...”, 68.
} 
Beksaç, Engin. "Mescid-i Şah." Türkiye Diyanet Vakfi İslam Ansiklopedisi (DIAA). XXIX: 291-293. Ankara: TDV Yayınları, 2004.

Blair, Sheila, ve Johnathan Bloom. "Safevi Dönemi Mimarisi." içinde $\dot{I}_{s-}$ lam Sanatı ve Mimarisi, editör Markus Hattstein ve Peter Delius, 504-19 . İstanbul: Literatür Yayınları, 2007.

Burckhardt, Titus. İslam Sanatı: Dil ve Anlam. Çeviren Turan Koç. İstanbul: Klasik Yayınları, 2016.

Canby, Sheila R. The Golden Age of Persian Art ( 1501 - 1722). London: The British Museum Press, 1999.

Carswell, John. New Julfa: The Armenian Churches and Other Buldings. Oxford: Clarendon Press, 1968.

Dalkıran, Sayın. "İran Safevi Devleti'nin Kuruluşuna Şii İnançların Etkisi ve Osmanlı'nın İran'a Bakışı." Atatürk Üniversitesi Illahiyat Fakültesi Dergisi, no. 18 (2002): 55-102. Son Erişim: 10 Mart 2020. http://isamveri. org/pdfdrg/D00018/2002_18/2002_18_DALKIRANS.pdf.

Davari, Nazanin, ve Jamshid Hatam. "Safevi Döneminde Avrupa Tarzı Duvar Resimleri: Bir Sanat Tarihi Okuması." Iran Çalışmaları Dergisi 2, no.1 (2018): 121-169.

Doğanay, Aziz. Osmanlı Tezyinatı-Klasik Devir Osmanlı Hanedan Türbeleri (1522-1604). İstanbul: Klasik Yayınları, 2009.

Doğanay, Aziz. "Çini." içinde İslâm Sanatları Tarihi, editör Muhittin Serin, 170-193. Eskişehir: Anadolu Üniversitesi Yayınları, 2010.

Gündüz, Tufan. "Safevîler." Türkiye Diyanet Vakfi İslam Ansiklopedisi, XXXV: 451-457. İstanbul: TDV Yayınları, 2008.

Golombek, Lisa. "Anatomy of a Mosque: Masjed-e Shah in Isfahan.” içinde Iranian Civilization and Culture, editör Charles J. Adams, 5-14. Montreal : McGill University Press, 1973.

Grabar, Oleg. İslam Sanatının Oluşumu. Çeviren Nuran Yavuz. İstanbul: Kanat Yayınları, 2004.

Hakhnazarian, Armen. "Julfa iv. Architecture and Painting." Encyclopedia Iranica 15, no. 3 (2009): 238-240. Son Erişim: 14 Nisan 2020. http://www. iranicaonline.org/articles/julfa-iv-architecture-and-painting. 
-. Nor Djulfa - The Churches of The Armenian. Tehran: Ferhangestân Honar, 1991.

Hatami, Aziz. Persepolis Pasargade and Naghsh-e-Rustem. Tehran: The General Department of Publications and Broadcasting, tarih yok.

Hattstein, Markus. “İran Safeviler ve Kaçarlar.” içinde İslam Sanatı ve Mimarisi, ed. Markus Hattstein ve Peter Delius, İstanbul: Literatür Yayıları, 2007.

Hillenbrand, Robert. İslam Sanatı ve Mimarlı̆̆ı. Çeviren Çiğdem Kafesçioğlu. İstanbul: Homer Yayınları, 2005.

Hillenbrand, Robert. "Safavid Architecture. " Cilt VI, içinde The Cambridge History of Iran - The Timurid and Safavid Periods, ed. Peter J. Jackson, 759-842. Cambridge : Cambridge University Press, 1986.

Holakooei, Parviz. "Technological study of the seventeenth century haft rang tiles in Iran with a comparative view to the cuerda seca tiles in Spain". Doktora Tezi, Università degli Studi di Ferrara, 2013. Son Erişim: 16 May1s 2019. http://eprints.unife.it/780/1/PhD\%20Thesis_Holakooei_PDFA. pdf.

Hubbard, Isabel. "Ali Rıza-i Abbasî, Calligrapher and Painter." Ars Islamica 4, (1937): 282-291. Son Erişim: 1 Nisan 2019. https://www.jstor.org/ stable/25167043.

Keyanî, Muhammed Yusuf. İslam Dönemi İran Mimarisi. Ankara: İraniyat Yayınlar1, 2018.

Khajegir, Ali Reza, Mohammad Reza Afroogh, ve Ali Reza Fahim. "The Art of Islamic Architecture during the Safavid Period and the Introduction of the Teachings of Islam." Journal of Fine Arts 1, no. 3 (2018): 37-42. Son Erişim: 23 Mart 2019. https://www.sryahwapublications.com/journal-offine-arts/pdf/v1-i3/5.pdf.

Khakpour, Minoo, ve Fatemeh Kateb. "A Comparative Study of Religious Architecture in Christianity and Islam A Criticism of Titus Burckdardt's Theory (Case study: Isfahan)." Bagh-e Nazar 14, no. 50 (2017): 57-68. Son Erişim: 3 Mart 2019. https://www.researchgate.net/ publication/319006408_A_Comparative_Study_of_Religious_Architecture_in_Christianity_and_Islam_A_Criticism_of_Titus_Burckhardt's_ Theory. 
Landau, Amy S. "European Religious Iconography in Safavid Iran: Decoration and Patronage of Meydani Bet'ghehem (Bethlehem of the Maydan)." içinde Iran And The World In The Safavid Age, editör Willem Floor ve Edmund Herzig, 425-446. London: I.B. Tauris Yayınları, 2015.

Landau, Amy S., ve Theo Maarten Van Lint. "Armenian Merchant Patronage of New Julfa's Sacred Spaces." içinde Sacred Precincts: The Religious Architecture of Non-Muslim Communities across the Islamic World, editör M. Gharipour. Leiden-Boston: Brill, 2015. Son Erişim: 11 Nisan 2020. https://www.academia.edu/37913425/_Armenian_Merchant_Patronage_of_New_Julfa_s_Sacred_Spaces_.

Mülayim, Selçuk. İslam Sanatı. İstanbul: İSAM Yayınları, 2010.

O'Kane, Bernard. Studies in Persian Art and Architecture. Cairo: The American University in Cairo Press, 1995.

Olyaei, Bahman Razi. “17. Yüzyıl'da Avrupa Görsel Sanat Eserlerinin İran'ın Geleneksel Resmine Etkisi.” Sanat Tarihi Yıllı̆̆l, no. 27 (2018): 217-274.

Parvazi, Elham, ve Hassanali Pourmand. "Teceli âlem mesâl der tez'inât-e me'mâri esr-e Safevî (Nemûne mûredi: Mesced-e Emâm Esfehân)." Ârmânshahr Journal - Architecture and Urban Development 5, no. 9 (1391/2013): 31-44. Son Erişim: 15 Nisan 2019. http://www.armanshahrjournal.com/article_33206_4b6246f5cc24524f471d3887c9762417.pdf

Pope, Arthur Upham. "Safavid Period." Cilt III, içinde A Survey of Persian Art, editör Arthur Upham Pope, 1165-1225. Tehran: Soroush Press, 1977.

Rashidi, Reyhaneh, ve Shahryar Shokrpour. "The Study of the Influence of the Safavid Era Carpets on Animal Motifs in Murals of the Pirnia House." Journal of Faculty of Art Shahed University, no. 42, (2017): 82-98. Son Erişim: 6 Nisan 2019. http://negareh.shahed.ac.ir/article_532_1f85c12d31 f396bd2e7b5be30a176a93.pdf.

Sümer, Faruk. “Abbas I.” Türkiye Diyanet Vakfi İslam Ansiklopedisi. I/ 1719. İstanbul: TDV Yayınları, 1988.

Tanınd1, Zeren. “Topkapı Sarayı Kitap Hazinesi'nin Nadide Eserlerinden Bir Diğeri: Hazine 2166 Numaralı Safevî Albümü Hakkında.” Sanat Tarihi

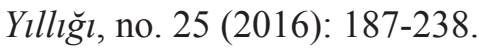


Utaberta, N., H. Mamamni, M. Surat, A. I. Che-Ani, ve N.A.G. Abdullah. "The Study on the Development of Ornamentation in the Architecture of Safavid Dynasty." World Academy of Science, Engineering and Technology International Journal of Civil, Environmental, Structural, Construction and Architectural Engineering 6, no. 7 (2012): 465-469. Son Erişim: 19 Mayıs 2019. https://waset.org/publication/The-Study-on-the-Development-ofOrnamentation-in-the-Architecture-of-Safavid-Dynasty/1879.

Uzun, Tolga. “İran'da Öykülü Resimlerin Dolaşımı: İslam Edebiyatının Popüler Konularının El Yazmalardan Tuvallere Taşınması Üzerine Bir Deneme.” Modern Türklük Araştırmaları Dergisi 5, no. 2 (2008): 127-154.

Yetkin, Şerare. "Çini." Türkiye Diyanet Vakfi İslam Ansiklopedisi. VIII: 329-335. İstanbul: TDV Yayınları, 1993.

\section{Internet Kaynakları}

Plan 1: Nakş-i Cihan meydanı Planı. Son Erişim: 25 Kasım 2019. https:// irantourismer.com/naghsh-e-jahan-square-imam-square/.

Foto. 2: Isfahan Mescid-i Şah. Son Erişim: 12 Aralık 2019. www.archnet.com.

Plan 2: Isfahan Mescid-i Şah Planı. Son Erişim: 25 Kasım 2019. http://www.ne.jp/asahi/arc/ind/2_meisaku/55_shah/sha_eng.htm.

Foto. 7: Isfahan Mescid-i Şah Taç Kapı Mukarnasında Yer Alan Karşılıklı İki Tavus Kuşu Figürü. Son Erişim: 10 Nisan 2019. https://www.alamy. com/detail-of-tile-work-entrance-portal-of-the-masjid-i-shah-isfahaniran-image62671142.html.

Foto. 13: Isfahan Yeni Culfa Bölgesinde Yer Alan Beytüllahim Kilisesi (17.yy) Absidi. Son Erişim:12 Ocak 2019. https://en.wikipedia.org/wiki/ Bedkhem_Church\#/media/File:Bedkhem_Church_09.jpg.

Foto. 14: Isfahan Yeni Culfa Bölgesinde Yer Alan Vank Katedrali (17. yy). Son Erişim: 12 Ocak 2019, https://www.flickr.com/photos/fengwei888/40102133471.

Foto. 15: Isfahan Yeni Culfa Bölgesinde Yer Alan Beytüllahim Kilisesi (17.yy) Duvar Çinileri. Son Erişim: 12 Ocak 2019. http://www.iranicaonline.org/articles/julfa-iv-architecture-and-painting\#prettyPhoto[content]/5/ . 
Foto. 16: Isfahan Yeni Culfa Bölgesinde Yer Alan Vank Katedrali (17.yy) Absidinde Çini Üzerinde Melek Motifi. Son Erişim: 12 Ocak 2019, https:// www.abebooks.com/collections/sc/religion/4vV9XXakaT6GbAFYIGyE $\mathrm{xZ}$.

Foto. 17: Isfahan Yeni Culfa Bölgesinde Yer Alan Beytüllahim Kilisesi (17.yy) Duvar Çinilerinden Detay. Son Erişim: 12 Ocak 2019, http://justinandcrystal.com/CentralAsia/CentralAsia-124.jpg. 